\title{
Recent Advances in Kaempferia Phytochemistry and Biological Activity: A Comprehensive Review
}

\author{
Abdelsamed I. Elshamy ${ }^{1,2}\left(\mathbb{D}\right.$, Tarik A. Mohamed ${ }^{3}$, Ahmed F. Essa ${ }^{2}$, \\ Ahmed M. Abd-El Gawad 4,5 ${ }^{\mathbb{D}}$, Ali S. Alqahtani 6,*(D), Abdelaaty A. Shahat ${ }^{3,6} \mathbb{D}_{\text {, }}$ \\ Tatsuro Yoneyama ${ }^{1}$, Abdel Razik H. Farrag ${ }^{7}$, Masaaki Noji ${ }^{1}$, Hesham R. El-Seedi ${ }^{8,9,10}$ (D), \\ Akemi Umeyama ${ }^{1}$ (D), Paul W. Paré ${ }^{11}$ (D) and Mohamed-Elamir F. Hegazy ${ }^{3,12, *(D)}$
}

1 Faculty of Pharmaceutical Sciences, Tokushima Bunri University, Yamashiro-cho, Tokushima 770-8514, Japan; elshamynrc@yahoo.com (A.I.E.); yoneyama@ph.bunri-u.ac.jp (T.Y.); mnoji@ph.bunri-u.ac.jp (M.N.); umeyama@ph.bunri-u.ac.jp (A.U.)

2 Chemistry of Natural Compounds Department, National Research Centre, 33 El Bohouth St., Dokki, Giza 12622, Egypt; ahmedfathyessa551@gmail.com

3 Chemistry of Medicinal Plants Department, National Research Centre, 33 El-Bohouth St., Dokki, Giza 12622, Egypt; tarik.nrc83@yahoo.com (T.A.M.); ashahat@ksu.edu.sa (A.A.S.)

4 Department of Botany, Faculty of Science, Mansoura University, Mansoura 35516, Egypt; dgawad84@mans.edu.eg

5 Plant Production Department, College of Food \& Agriculture Sciences, King Saud University, Riyadh 11451, Saudi Arabia

6 Pharmacognosy Department, College of Pharmacy, King Saud University, P.O. Box 2457, Riyadh 11451, Saudi Arabia

7 Pathology Department; National Research Centre, Dokki, Giza 12622, Egypt; abdelrazik2000@yahoo.com

8 Pharmacognosy, Department of Medicinal Chemistry, Uppsala University, Box 574, SE-75 123 Uppsala, Sweden; hesham.el-seedi@ilk.uu.se

9 Department of Chemistry, Faculty of Science, Menoufia University, Shebin El-Kom 32512, Egypt

10 College of Food and Biological Engineering, Jiangsu University, Zhenjiang 212013, China

11 Department of Chemistry \& Biochemistry, Texas Tech University, Lubbock, TX 79409, USA; paul.pare@ttu.edu

12 Department of Pharmaceutical Biology, Institute of Pharmacy and Biochemistry, University of Mainz, Staudinger Weg 5, 55128 Mainz, Germany

* Correspondence: alalqahtani@ksu.edu.sa (A.S.A.); mohegazy@uni-mainz.de (M.-E.F.H.); Tel.: +966-114677246 (A.S.A.); +49-6131-3925751 (M.-E.F.H.)

Received: 12 September 2019; Accepted: 1 October 2019; Published: 7 October 2019

Abstract: Background: Plants belonging to the genus Kaempferia (family: Zingiberaceae) are distributed in Asia, especially in the southeast region, and Thailand. They have been widely used in traditional medicines to cure metabolic disorders, inflammation, urinary tract infections, fevers, coughs, hypertension, erectile dysfunction, abdominal and gastrointestinal ailments, asthma, wounds, rheumatism, epilepsy, and skin diseases. Objective: Herein, we reported a comprehensive review, including the traditional applications, biological and pharmacological advances, and phytochemical constituents of Kaempheria species from 1972 up to early 2019. Materials and methods: All the information and reported studies concerning Kaempheria plants were summarized from library and digital databases (e.g., Google Scholar, Sci-finder, PubMed, Springer, Elsevier, MDPI, Web of Science, etc.). The correlation between the Kaempheria species was evaluated via principal component analysis (PCA) and agglomerative hierarchical clustering (AHC), based on the main chemical classes of compounds. Results: Approximately 141 chemical constituents have been isolated and reported from Kaempferia species, such as isopimarane, abietane, labdane and clerodane diterpenoids, flavonoids, phenolic acids, phenyl-heptanoids, curcuminoids, tetrahydropyrano-phenolic, and steroids. A probable biosynthesis pathway for the isopimaradiene skeleton is illustrated. In addition, 15 main documented components of volatile oils of Kaempheria 
were summarized. Biological activities including anticancer, anti-inflammatory, antimicrobial, anticholinesterase, antioxidant, anti-obesity-induced dermatopathy, wound healing, neuroprotective, anti-allergenic, and anti-nociceptive were demonstrated. Conclusions: Up to date, significant advances in phytochemical and pharmacological studies of different Kaempheria species have been witnessed. So, the traditional uses of these plants have been clarified via modern in vitro and in vivo biological studies. In addition, these traditional uses and reported biological results could be correlated via the chemical characterization of these plants. All these data will support the biologists in the elucidation of the biological mechanisms of these plants.

Keywords: Kaempferia; traditional medicine; diterpenoids; flavonoids; phenolic; biosynthesis

\section{Introduction}

From the first known civilization, medicinal plants have met primary care and health needs around the world [1-3]. Natural products, derived from plants, have enriched the pharmaceutical industry since time immemorial. So far, people of the developing countries depend upon the traditional medicines to cure daily aliments [4]. The medicinal plants are characterized by a diversity of chemical and pharmacological constituents, owing to their complicity and the abundance of secondary metabolites. There are several factors that caused the variations of the secondary metabolites such as ecological zones, weather, climates, and other natural factors via the effects on the biosynthetic pathways [1-3].

Zingiberaceae (the ginger family) is distributed worldwide comprising 52 genera and more than 1300 plant species [5,6]. Kaempferia is a diverse family with members distributed widely throughout Southeast Asia and Thailand, including some 60 species [5]. Several Kaempferia species are used widely in folk medicine, including K. parviflora, K. pulchra, and K. galanga, (Figure 1). In Laos and Thai, traditional medicines derived from K. parviflora rhizomes are reported for the treatment of inflammation, hypertension, erectile dysfunction, abdominal ailments [6,7], and improvement of the vitality and blood flow [8]. Japanese use the extract of K. parviflora as a food supplement and for the treatment of metabolic disorders [9]. K. pulchra is used extensively as a carminative, diuretic, deodorant, and euglycemic, as well as for the treatment of urinary tract infections, fevers, and coughs [4]. The rhizomes of K. galanga are used as an anti-tussive, expectorant, anti-pyretic, diuretic, anabolic, and carminative, as well as for the curing of gastrointestinal ailments, asthma, wounds, rheumatism, epilepsy, and skin diseases [10].

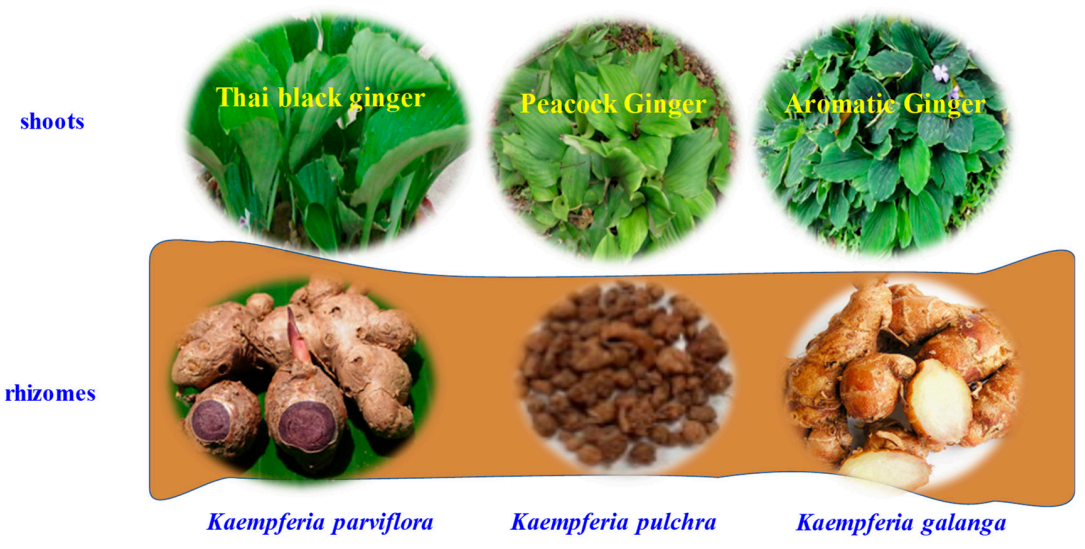

Figure 1. Traditional medicinal used Kaempheria species.

Extracts and purified compounds from select Kaempferia species are used for the treatment of knee osteoarthritis and the inhibition of a breast cancer resistance protein (BCRP), anti-inflammatory, anti-acne, anticholinesterase, anti-obesity-induced dermatopathy, wound healing, anti-drug resistant strains of Mycobacterium tuberculosis, neuroprotective, anti-nociceptive, human immunodeficiency 
virus type-1 (HIV-1) inhibitory activity, in vitro anti-allergenic, and larvicidal activity against Aedes aegypti [4,6-11]. The scientific literature such as, Google Scholar, Scifinder, PubMed, Springer, Elsevier, Wiley, Web of Science, were screened in the period between 1972-2019 in order to collect the up-to-date information of the traditional uses/applications, biological studies, and chemical characterization of Kaempheria species. All these collected data were addressed and summarized in our review article to highlight the potential ethnopharmacological importance of these plants.

\section{Materials and Methods}

The scientific literature such as Google Scholar, Scifinder, PubMed, Springer, Elsevier, Wiley, Web of Science, etc., including all the traditional uses/applications, biological studies, and chemical characterization of Kaempheria species were collected between 1972-2019. All these collected data were adjusted and summarized in our review article due to the potential ethnopharmacological importance of these plants.

The correlation between the Kaempheria species was evaluated based on the main chemical classes of compounds. The data matrix of seven Kaempferia species ( $K$. angustifolia, K. elegans, K. galanga, K. marginata, K. parviflora, K. pulchra, and K. roscoeana) and six chemical classes (abietanes, labdanes and clerodanes, flavonoids, phenolic compounds, and chalcones) were subjected to principal component analysis (PCA) to identify correlation between different Kaempferia species. In addition, the similarity based on the Pearson correlation coefficient was determined via subjecting the dataset to an agglomerative hierarchical cluster (AHC). The PCA and AHC were performed using an XLSTAT statistical computer software package (version 2018, Addinsoft, NY, USA, www.xlstat.com).

\section{Distribution}

Zingiberaceae (the ginger family) comprises 52 genera and more than 1300 plant species. Kaempferia is distributed worldwide with diverse members occurring throughout southeast tropical Asian countries such as Indonesia, India, Malaysia, Myanmar, Cambodia, and China, as well as Thailand, including some 60 species [5]. K. pulchra is a perennial herbal plant and widely cultivated in numerous tropical countries, involving Indonesia, Malaysia, Myanmar, and Thailand [12].

\section{Traditional Uses}

Several Kaempferia species are used widely in folk medicine, including K. parviflora, K. pulchra, and K. galanga (Figure 1). In Laos and Thai, traditional medicines derived from K. parviflora rhizomes are reported for the treatment of inflammation, hypertension, erectile dysfunction, abdominal ailments [6,7], and improvement of the vitality and blood flow [8]. Japanese folk medicine documented a positive effect of K. parviflora extract when used as a food supplement and for the treatment of metabolic disorders [9]. K. pulchra is used extensively as a carminative, diuretic, deodorant, and euglycemic, as well as for the treatment of urinary tract infections, fevers, and coughs [4]. K. galanga is sold as an industrial crop in the market, and its rhizome has been used as a flavor spice of various cooking [13]. The rhizomes of K. galanga is used as an anti-tussive, expectorant, anti-pyretic, diuretic, anabolic, carminative, as well as for curing of gastrointestinal ailments, asthma, wounds, rheumatism, epilepsy, and skin diseases [10]. In Malaysian folk medicines, several gingers belonging to the Zingiberaceae family especially, Kaempheria genus, are used in the treatment of several diseases such as stomach ailments, vomiting, cough, bruises, epilepsy, nausea, rheumatism, sore throat, wounds, eyewash, sore eyes, childbirth, liver complaints, muscular pains, ringworm, asthma, fever, malignancies, swelling, and several other disorders [14].

\section{Biological Activity}

Extracts and purified compounds of Kaempferia species are used for the treatment of knee osteoarthritis and the inhibition of a breast cancer resistance protein (BCRP), anti-inflammatory, anti-acne, anticholinesterase, anti-obesity-induced dermatopathy, wound healing, anti-drug resistant 
strains of Mycobacterium tuberculosis, neuroprotective, anti-nociceptive, human immunodeficiency virus type-1 (HIV-1) inhibitory activity, in vitro anti-allergenic, and larvicidal activity against Aedes aegypti [11]. Kaempheria plant extracts and isolated compounds demonstrate numerous and promising biological and pharmaceutical activities, which are summarized in Figure 2.

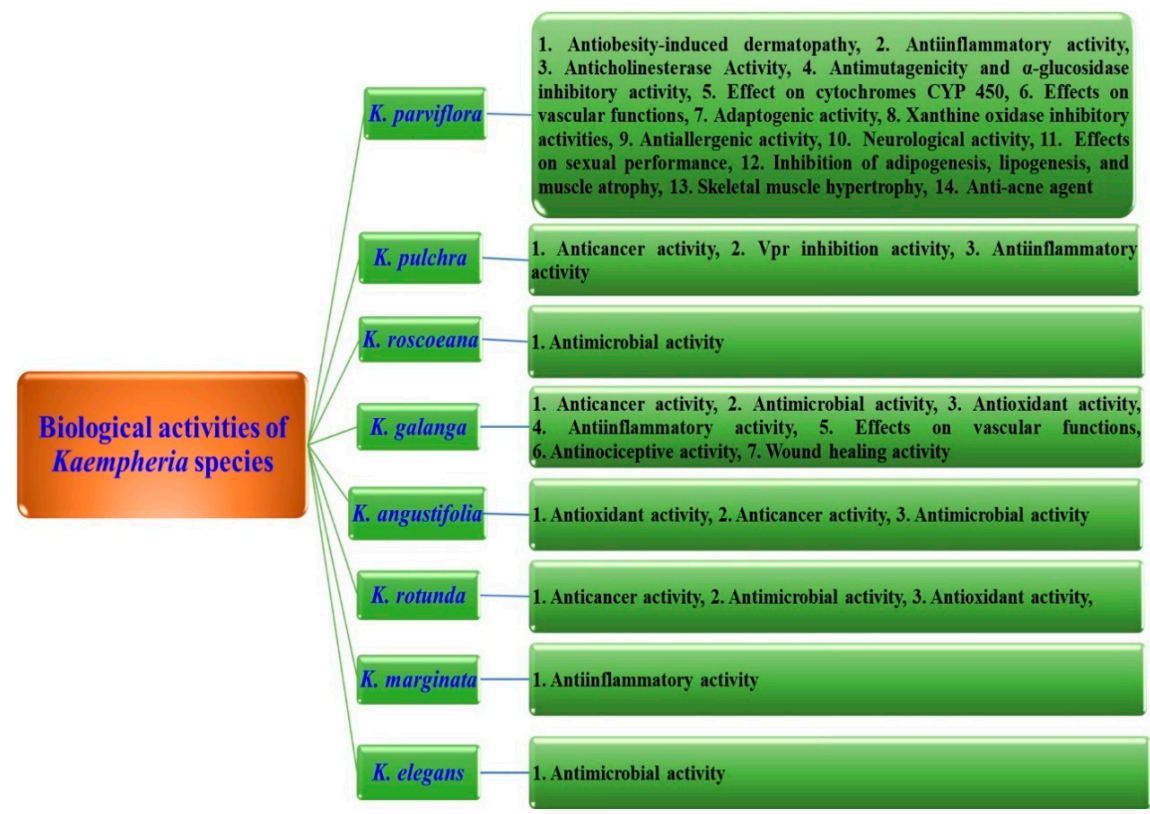

Figure 2. Reported biological activities for Kaempheria species.

\subsection{Anticancer Activity}

Rhizome ethanolic extracts of $K$. galanga and the purified component ethyl trans p-methoxycinnamate (105) demonstrate moderate cytotoxic activity against human cholangiocarcinoma (CL-6) cells with $\mathrm{IC}_{50}$ of 64.2 and $49.4 \mu \mathrm{g} \mathrm{mL}{ }^{-1}$, respectively. Significant cholangiocarcinoma (CCA) efficacy as indicated by suppressing tumor growth and lung metastasis in CL6-xenografed mice [15] is also observed. Swapana et al. [16] documented that K. galanga isopimarene diterpenoids, sandaracopimaradiene-9 $\alpha$-ol (2), kaempulchraol I (14), and kaempulchraol L (17) exhibit promising activity against human lung cancer with $\mathrm{IC}_{50}$ of $75 \mu \mathrm{M}, 74 \mu \mathrm{M}$, and $76 \mu \mathrm{M}$, respectively, and mouth squamous cell carcinoma (HSC-2) inhibition with $\mathrm{IC}_{50}$ of $70 \mu \mathrm{M}, 53 \mu \mathrm{M}$, and $58 \mu \mathrm{M}$, respectively [16]. The latter compound, isolated from K. pulchra, is reported to have weak anti-proliferative activity against human pancreatic and cervix cancers [17]. Chawengrum et al. [18] stated that K. pulchra labdene diterpenoids, (-)-kolavelool (81), and (-)-2 $\beta$-hydroxykolavelool (82) exhibit cytotoxic activity against human leukemia cells (HL-60) with $\mathrm{IC}_{50}$ values of $9.0 \pm 0.66$ and $9.6 \pm 0.88 \mu \mathrm{g} \mathrm{mL}^{-1}$, respectively [18]. Acetone, petroleum ether, chloroform, and $\mathrm{MeOH}$ extracts of $K$. galanga rhizomes show moderate cytotoxicity in a brine shrimp lethality bioassay compared with vincristine sulfate as the reference compound [19]. Moreover, a methanolic extract of K. galanga rhizomes induces Ehrlich ascites carcinoma (EAC) cell death in a dose-dependent manner [20]. 5,7-Dimethoxyflavone (86) isolated from K. galanga was found to reduce cancer resistance to tyrosine kinase inhibitors (TKI) by inhibiting breast cancer resistance protein (BCRP), one of the efflux transporters that increased efflux of TKI out of cancer cells. This was observed both in vitro with a dose-dependent increase in the intracellular concentration of sorafenib in MDCK/BCRP1 breast cancer resistance cells, with an $\mathrm{EC}_{50}$ of $8.78 \mu \mathrm{M}$ as well as in vivo by increasing sorafenib AUC in mice tissues when co-administered with compound 88, as reported by kinetic results [21]. The isolated methyl- $\beta$ - $D$-galactopyranoside specific lectin from the rhizome of $K$. rotunda exhibited in vitro antitumor activity against Ehrlich ascites carcinoma cells at a $\mathrm{pH}$ between 6-9 and a temperature range between $30-80^{\circ} \mathrm{C}$. Tumor inhibition was also observed in vivo in EAC-bearing mice [22]. 
The cytotoxicity of $\mathrm{MeOH}$, petroleum ether, and EtOAc extracts against C33A cancer cells via MTT and scratch assays compared with essential oils of K. galanga rhizomes showed activity for the EtOAc and $\mathrm{MeOH}$ fractions at $1000 \mu \mathrm{g} \mathrm{mL} \mathrm{m}^{-1}$ with $11 \%$ and $14 \%$ cell viability and weak efficacy with petroleum ether extracted essential oils in a MTT assay. Cell growth inhibition was observed with all extracts in the scratch assay [23]. Compound (140) isolated from K. angustifolia was described to have strong activity with an $\mathrm{IC}_{50}$ of $1.4 \mu \mathrm{g} \mathrm{mL} \mathrm{m}^{-1}$, which was comparable to 5-fluorouracil as a reference drug. Compound (138) also showed moderate inhibition against human lung cancer. $2^{\prime}$-Hydroxy-4,4',6'-trimethoxychalcone (flavokawain A; 119) exhibited potent activity against HL-60 and MCF-7 cell lines. The results of Tang et al. [24] revealed that flavokawain A (119) exhibited cytotoxic activity against MCF-7 and HT-29 cell lines with GI $_{50}$ values of $17.5 \mu \mathrm{M}\left(5.5 \mu \mathrm{g} \mathrm{mL}^{-1}\right)$ and $45.3 \mu \mathrm{M}\left(14.2 \mu \mathrm{g} \mathrm{mL}^{-1}\right)$, respectively. Kaempfolienol (65) and zeylenol (133) were also found to have moderate activity against HL-60 and MCF-7 cells with $\mathrm{IC}_{50}$ values $<30 \mu \mathrm{g} \mathrm{mL}{ }^{-1}$ and against HL-60 only with an $\mathrm{IC}_{50}$ value of $11.6 \mu \mathrm{g} \mathrm{mL}^{-1}$ respectively [24].

\subsection{Anti-Obesity Activity}

An ethanolic extract, a polymethoxyflavonoid-rich fraction (PMF) and a polymethoxyflavonoid-poor fraction from K. parviflora were screened against an obesity-induced dermatopathy system using Tsumura Suzuki obese diabetes (TSOD) mice as an obesity model (Hidaka, Horikawa, Akase, Makihara, Ogami, Tomozawa, Tsubata, Ibuki, and Matsumoto) [11]. The ethanolic extract reduced mouse body weight and the thickness of the subcutaneous fat layer more than the PMF fraction that is used as a dietary supplement in controlling skin disorders caused by obesity [11].

\subsection{Anti-HIV Activity}

Viral protein $\mathrm{R}(\mathrm{Vpr})$ is one of the HIV accessory proteins that can be targeted for controlling viral replication and pathogenesis. $\mathrm{A} \mathrm{CHCl}_{3}$ fraction of $\mathrm{K}$. pulchra exhibits Vpr-inhibitory activity at $251 \mathrm{~g} \mathrm{~mL}^{-1}$. In addition, isopimarene type diterpenoids isolated from the rhizomes of the plants, kaempulchraol B (43), kaempulchraol D (45), kaempulchraol G (46), kaempulchraol Q (20), kaempulchraol T (36), kaempulchraol U (50), and W (22) inhibit the expression of Vpr at concentrations from 1.56 to $6.25 \mu \mathrm{M}$ [25].

\subsection{Antimicrobial Activity}

Arabietatriene (62) isolated from K. roscoeana exhibits antibacterial activity against Gram-positive bacteria Staphylococcus epidermidis and Bacillus cereus [26]. Anticopalic acid (72), anticopalol (77), and 8(17)-labden-15-ol (68) isolated from $K$. elegans also exhibited antibacterial activity against $B$. cereus [18]. Acetone, petroleum ether, chloroform, and $\mathrm{MeOH}$ extracts of $K$. galanga rhizomes exhibit moderate antibacterial activity against Gram-positive and Gram-negative bacteria in comparison with ciprofloxacin [19]. Ethyl p-methoxycinnamate (105) also isolated from K. galanga rhizomes have been shown based on a resazurin micro-titer assay to inhibit Mycobacterium tuberculosis H37Ra, H37Rv, multidrug-resistant, and drug-susceptible isolates with MIC $0.242-0.485 \mathrm{mM}$ [27]. Its essential oil also displays strong antibacterial activity against Staphylococcus aureus and Salmonella typhimurium, and weak activity against Escherichia coli [28]. Moreover, essential oils extracted from three varieties of K. galanga exhibited potent larvicidal activity [29]. An ethyl acetate extract of K. rotunda inhibits S. aureus and E. coli [30]. A rhizomes extract of K. galanga inhibits Epstein-Barr virus with no cytotoxic effect in Raji cells [14]. In contrast, isolated diterpenoids from K. roscoeana exhibited no activity against Plasmodium falciparum (Chloroquine-resistant) [26]. Fauziyah et al. [31] described that an ethanolic extract of K. galanga alone exhibits $100 \%$ growth inhibition of the multi-drug resistant (MDR) Mycobacterium tuberculosis (isolates at $500 \mu \mathrm{g} \mathrm{mL}^{-1}$ ). However, a combination of this extract with streptomycin, ethambutol, and isoniazid showed inhibition values of $55 \%, 76 \%$, and $50 \%$, respectively. Ethanol, methanol, petroleum ether, chloroform, and aqueous extracts of K. galanga rhizome showed antimicrobial activity against human pathogenic bacteria and fungi, while the ethanolic extract exhibited 
the strongest inhibition of $S$. aureus using an inhibition zone assay [32]. However, flavokawain A (119) and other compounds reported from K. angustifolia had no antimicrobial activity against tested microbes [24].

\subsection{Antioxidant Activity}

The $\mathrm{CHCl}_{3}$ and $\mathrm{MeOH}$ extracts of the rhizomes of $\mathrm{K}$. angustifolia showed strong antioxidant activity against DPPH expressed with $615.92 \mathrm{mg}$ trolox equivalent (TE)/g of extract. In an azinobis (3-ethyl-benzothiazoline-6-sulfonic acid) (ABTS) assay, $\mathrm{MeOH}$ extracts showed good antioxidant properties with a value of $38.87 \mathrm{mg} \mathrm{TE} / \mathrm{g}$. However, $n$-hexane extract exhibited significant antioxidant activity with $901.76 \mathrm{mg} \mathrm{TE} / \mathrm{g}$ in a cupric-reducing antioxidant capacity assay, while EtOAc extract exhibited significant reduction ability against ferric reducing antioxidant power (FRAP) with a value of $342.23 \mathrm{mg} \mathrm{TE} / \mathrm{g}$. Also, kaempfolienol (65) showed potent free radical scavenging activity in a DPPH assay, as well as, $2^{\prime}$-hydroxy-4,4', $6^{\prime}$-trimethoxychalcone (119) in ABTS, CUPRAC, and FRAP assays [33,34]. A methanol extract of rhizomes of $K$. galanga exhibited a concentration-dependent antioxidant activity in DPPH, ABTS, and nitric oxide (NO) radical scavenging assays [20]. Moreover, the essential oil extracts of conventionally propagated and in vitro propagated K. galanga had significant DPPH radical scavenging activity [35]. As well, the ethanol extract of $K$. rotunda exhibited antioxidant activity in a DPPH assay with $\mathrm{IC}_{50}\left(67.95 \mu \mathrm{g} \mathrm{mL} \mathrm{mL}^{-1}\right)$ [30].

\subsection{Anti-Inflammatory Activity}

The cyclohexane, chloroform, and ethyl acetate extracts with diarylheptanoids isolated from K. galanga showed a pronounced inhibition of Lipopolysaccharides (LPS)-induced nitric oxide in macrophage RAW 264.7 cells compared with indomethacin [13]. The EtOH extract and compounds $(1,52,53,119,120)$ isolated from $K$. marginata had promising anti-inflammatory activity based on the suppression of NO production and inducible nitric oxide synthase (iNOS) mRNA and cyclooxygenase-2 (COX-2) genes expression [36,37]. Diterpenoids (9-10) isolated from K. pulchra had topical anti-inflammatory activity in 12-O-tetradecanoylphorbol-13-acetate-induced ear edema in rats with ID 50330 and $50 \mu \mathrm{g} /$ ear, respectively. Biological activity may be due to the activation of Maxi-K channels in neurons and smooth muscles [38]. The ethanol extract of $K$. parviflora exhibited potent inhibition of PGE2. The plant extract and $3^{\prime}, 4^{\prime}, 5,7$-tetramethoxyflavone (86) were also reported to exhibit a dose-dependent inhibition of iNOS-mRNA expression. Additionally, $\mathrm{H}_{2} \mathrm{O}, \mathrm{EtOH}, \mathrm{EtOAC}$, $\mathrm{CHCl}_{3}$, and $n$-hexane soluble sub-fractions exhibited good in vivo anti-inflammatory activity by decreasing rat paw edema [39]. An 80\% EtOH extract reduced UV-induced COX-2 expression in mice skin that was attributed to the anti-oxidative activity of polyphenolics against the oxidizing properties of UV radiation [40]. A $60 \%$ EtOH and EtOAc-soluble fraction of 100\% methanol extracts of K. parviflora decreased knee osteoarthritis, which was likely due to methoxylated flavones [41]. Ethyl p-methoxycinnamate (105) isolated from K. galana inhibited cytokines as IL-1 and TNF $\alpha$ and endothelial function in rats [42].

Tewtrakul, et al. [43] found that the isolated methoxylated flavonoids from K. parviflora, 5-hydroxy-3,7,3', 4' -tetramethoxyflavone (96), 5-hydroxy-7,4'-dimethoxyflavone (93), and 5-hydroxy-3,7,4'-trimethoxyflavone (95) exhibited anti-inflammatory activity against the PGE 2 production, with $\mathrm{IC}_{50}$ values of $16.1 \mu \mathrm{M}, 24.5 \mu \mathrm{M}$, and $30.6 \mu \mathrm{M}$, respectively [43]. Tewtrakul and Subhadhirasakul [44] described methoxyflavones 96, 93, and 95 from a hexane extract of K. parviflora rhizomes that exhibited activity against $\mathrm{NO}$ release in $\mathrm{RAW}_{264.7}$ cells with $\mathrm{IC}_{50}$ values of $16.1 \mu \mathrm{M}$, $24.5 \mu \mathrm{M}$, and $30.6 \mu \mathrm{M}$, respectively. In addition, 5-hydroxy-3,7,3',4'-tetramethoxyflavone (96) inhibited $\mathrm{PGE}_{2}$ release with an $\mathrm{IC}_{50}$ value of $16.3 \mu \mathrm{M}$, with negative activity on Tumor Necrosis Factor alpha (TNF- $\alpha$ ) with $\mathrm{IC}_{50}>100 \mu \mathrm{M}$ [44]. Petroleum ether extract from K. galanga was active against acute inflammation at $300 \mathrm{mg} / \mathrm{kg}$ in rats and inhibited the inflammation and MPO levels at $100 \mathrm{mg} \mathrm{kg}^{-1}$ in the chronic model [45]. 


\subsection{Anticholinesterase Activity}

According to Sawasdee et al. [46], a MeOH extract as well as compounds (86-87) isolated from K. parviflora rhizomes inhibited acetylcholinesterase (AChE) and butyrylcholinesterase (BChE) with greater cholinesterase inhibitory toward $\mathrm{AChE}$ and $\mathrm{BChE}$ for (86), which was an observation of significance in the treatment of Alzheimer's disease [46].

\subsection{Anti-Mutagenicity Activity}

$\mathrm{CH}_{2} \mathrm{Cl}_{2}$ and EtOAc soluble fractions of $K$. parviflora showed anti-mutagenicity and $\alpha$-glucosidase inhibitory activity. Isolated methoxylated compounds $(\mathbf{8 6}, \mathbf{9 7}, \mathbf{8 4}$, and $\mathbf{9 2})$ from these extracts exhibited potent activity with $\mathrm{IC}_{50}$ values of $0.40,0.40,0.42$, and $0.47 \mathrm{nmol} / \mathrm{plate}$, respectively. Compounds (88, 87, and 91), also showed significant activity with $\mathrm{IC}_{50}$ values of $20.4 \mu \mathrm{M}, 54.3 \mu \mathrm{M}$, and $64.3 \mu \mathrm{M}$, respectively [47].

\subsection{Effect on Cytochromes CYP 450}

The results listed by Ochiai et al. [48] stated that the continued ingestion of (88) isolated from K. parviflora decreases liver CYP3A expression, which in turn increased levels of compounds metabolized by CYP3As such as midazolam [48].

\subsection{Vascular Activity}

The oral administration of $\mathrm{CH}_{2} \mathrm{Cl}_{2}$ extract of $K$. parviflora in middle-aged rats was found to decrease vascular responses to phenylephrine, increase acetylcholine-induced vasorelaxation and the production of nitric oxide (NO) from blood vessels, and decrease visceral, subcutaneous fat, fasting serum glucose, triglyceride, and liver lipid accumulation [49]. The effect of intravenous administration of a $\mathrm{CH}_{2} \mathrm{Cl}_{2}$ extract of $K$. galanga to rats reduced the mean arterial blood pressure [50]. This anti-hypertensive effect was attributed to ethyl cinnamate, which is a major compound in the extract [50]. The ethanol extract of rhizomes of K. parviflora caused dose-dependent relaxation on aortic rings as well as ileum pre-contracted with phenylephrine and acethylcholine [51].

\subsection{Adaptogenic Activity}

Hexane, chloroform, methanol, and ethanol extracts of K. parviflora exhibited adaptogenic activity compared with a crude ginseng root powder used as a reference [52]. A single oral dose of K. parviflora rhizome (60\% EtOH extract) increased the whole-body potential expenditure in humans [53]. K. parviflora was also found to improvement physical fitness and health by decreasing oxidative stress [54].

\subsection{Xanthine Oxidase Inhibitory Activity}

Among the isolated methoxylated flavonoids from K. parviflora, (87 and 86) inhibit xanthine oxidase activity with $\mathrm{IC}_{50}$ values of 0.9 and $>4 \mathrm{mM}$, respectively [9].

\subsection{Allergenic Activity}

Isolated polymethoxyflavones from $\mathrm{K}$. parviflora $(\mathbf{8 6}, \mathbf{9 7})$, in addition to $\mathrm{CH}_{2} \mathrm{Cl}_{2}, \mathrm{EtOAc}$, and $\mathrm{H}_{2} \mathrm{O}$ extracts, alleviated type I allergy symptoms through suppressing Rat Basophilic Leukemia cells (RBL-2H3) cell degranulation, with (92) and (94) showing the highest anti-allergenic activity [55].

\subsection{Neurological Activity}

A methanolic extract $(95 \% \mathrm{MeOH})$ of $\mathrm{K}$. parviflora exhibited neuroprotective activity by increasing rat hippocampus serotonin, norepinephrine, and dopamine levels in comparison with a vehicle-treated group [56]. An acetone extract of K. galanga rhizomes and leaves also exhibited central nervous system depressant activity [57]. 


\subsection{Nociceptive Activity.}

A K. galanga rhizome extract exhibited anti-nociceptive activity in rats that was stronger than aspirin but weaker than morphine. The efficacy was abolished by naloxone, suggesting that the analgesic effect may be centrally and peripherally mediated [58].

\subsection{Wound-Healing Activity}

The co-administration of a $K$. galanga rhizomes extract $(95 \% \mathrm{EtOH})$ with dexamethazone was found to have wound-healing activity in mice comparable to dexamethazone only [59].

\subsection{Effects on Sexual Performance}

Several 7-methoxyflavones $(\mathbf{8 6}, \mathbf{8 7}, \mathbf{8 9}, \mathbf{9 1}, \mathbf{9 3 - 9 5})$ isolated from $K$. parviflora rhizomes improved sexual activity in males through the inhibition of PDE5, with 86 being the most potent [60]. The activity was attributed to methoxyls present at positions C5 and C7 [60]. K. parviflora rhizome extracts, standardized to 5\% DMF, also improve erectile function in healthy men [61]. A K. parviflora extract as well as 5,7-dimethoxyflavones augment testosterone production, which decreases age-related diseases and hypogonadism [62]. Improved testosterone levels, sperm count, and sexual performance was observed in streptozotocin (STZ)-induced diabetic rats when treated with a K. parviflora extract (aqueous with $1 \%$ Tween-80) [63].

\subsection{Miscellaneous}

The rhizome extract ( $95 \%$ ethanolic) of K. parviflora reduced obesity via the inhibition of adipogenesis, lipogenesis, and muscle atrophy in mice [64]. In contrast, the K. parviflora derivatives of 5-hydroxy-7-methoxyflavone induce skeletal muscle hypertrophy [65]. A K. parviflora extract (95\% $\mathrm{EtOH})$ served as a potential anti-acne agent with anti-inflammatory, sebostatic, and anti-propioni bacteria activity [66].

Recently, K. parviflora alcoholic extract at 3-30 $\mu \mathrm{g} \mathrm{mL} \mathrm{m}^{-1}$ was evaluated regarding the molecular mechanisms associated with rheumatoid arthritis for up to $72 \mathrm{~h}$ compared with the dexamethasone as positive control [67]. They documented that the EtOH extract significantly decreased the gene expression levels of pro-inflammatory cytokines, inflammatory mediators, and matrix-degraded enzymes, but neither induced apoptosis nor altered the cell cycle. They also reported that the alcoholic extract inhibits cell migration, reduces the mRNA expression of cadherin-11, and selectively reduces the phosphorylation of mitogen-activated protein kinases (P38, MAPKs), signal transducers, and activators of transcription 1 (STAT1) and 3 (STAT3) signaling molecules, without interfering with the NF-kB pathway [67].

A K. galanga extract (acetone, petroleum ether, chloroform, or methanolic) exhibited dose-dependent anthelmintic activity with strong paralytic activity within one hour and death within $80 \mathrm{~min}$ at a $25 \mathrm{mg} \mathrm{mL}^{-1}$ concentration [68].

\section{Chemical Metabolites of Kaempferia Species}

Chemical profiles of Kaempferia exhibited the presence of different types of secondary metabolites such as terpenoids, especially isopimarane phenolic compounds, diarylheptanoids [13], flavonoids [69-71], and essential oils [72,73]. This review summarized the reported variety of compound types, including isopimarane, abietane, labdan, and clerodane diterpenoids, flavonoids, phenolic acids, phenyl-heptanoids, curcuminoids, tetrahydropyrano-phenolic, and steroids. Diterpenoids, especially isopimarane types, were the most reported compounds from the plants of this genus, in addition to phenolics, flavonoids, and essential oils. Each class will be described and listed in the following items, and the structures will be summarized in Tables 1-3. 
Table 1. Diterpenoids.

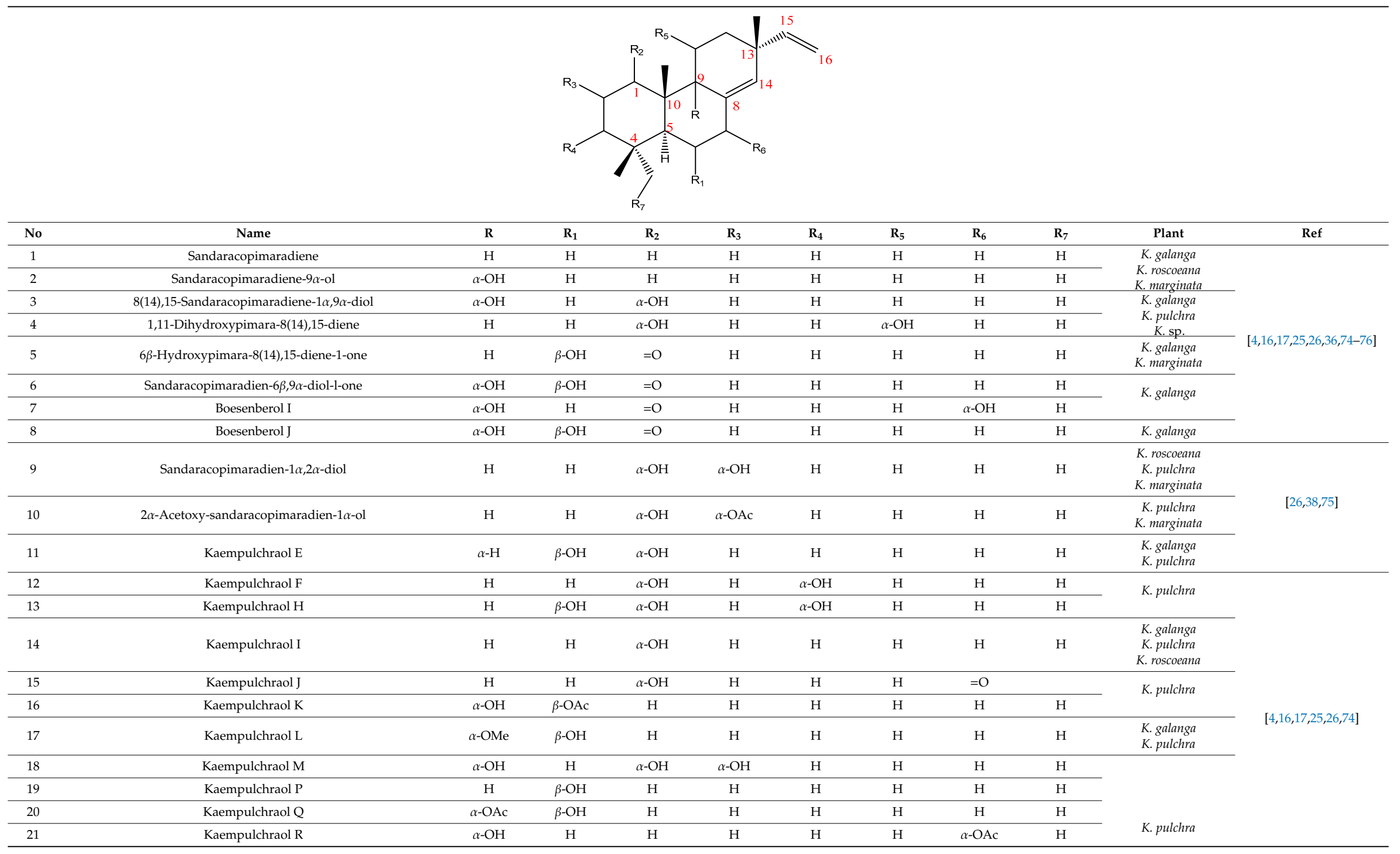


Table 1. Cont

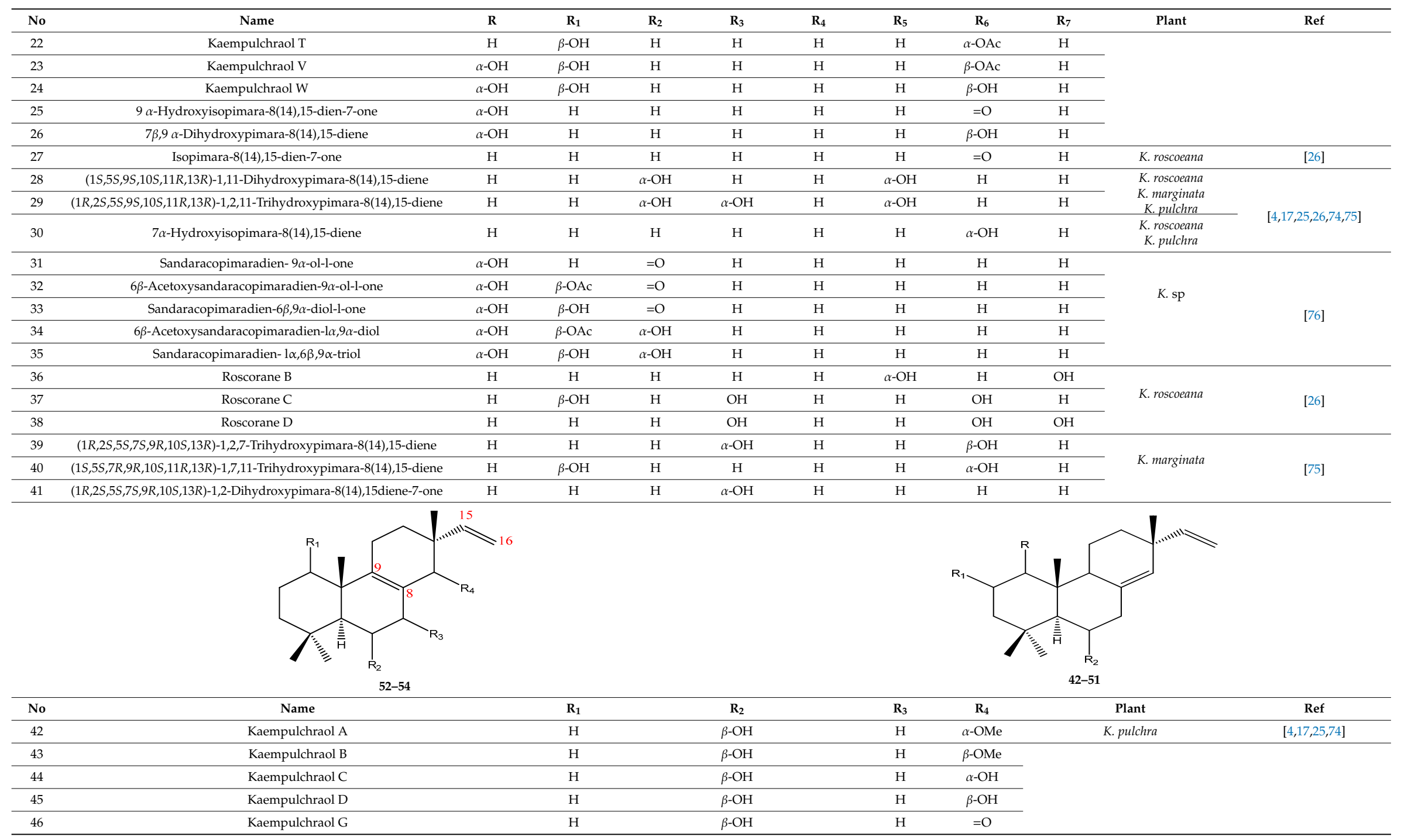


Table 1. Cont.

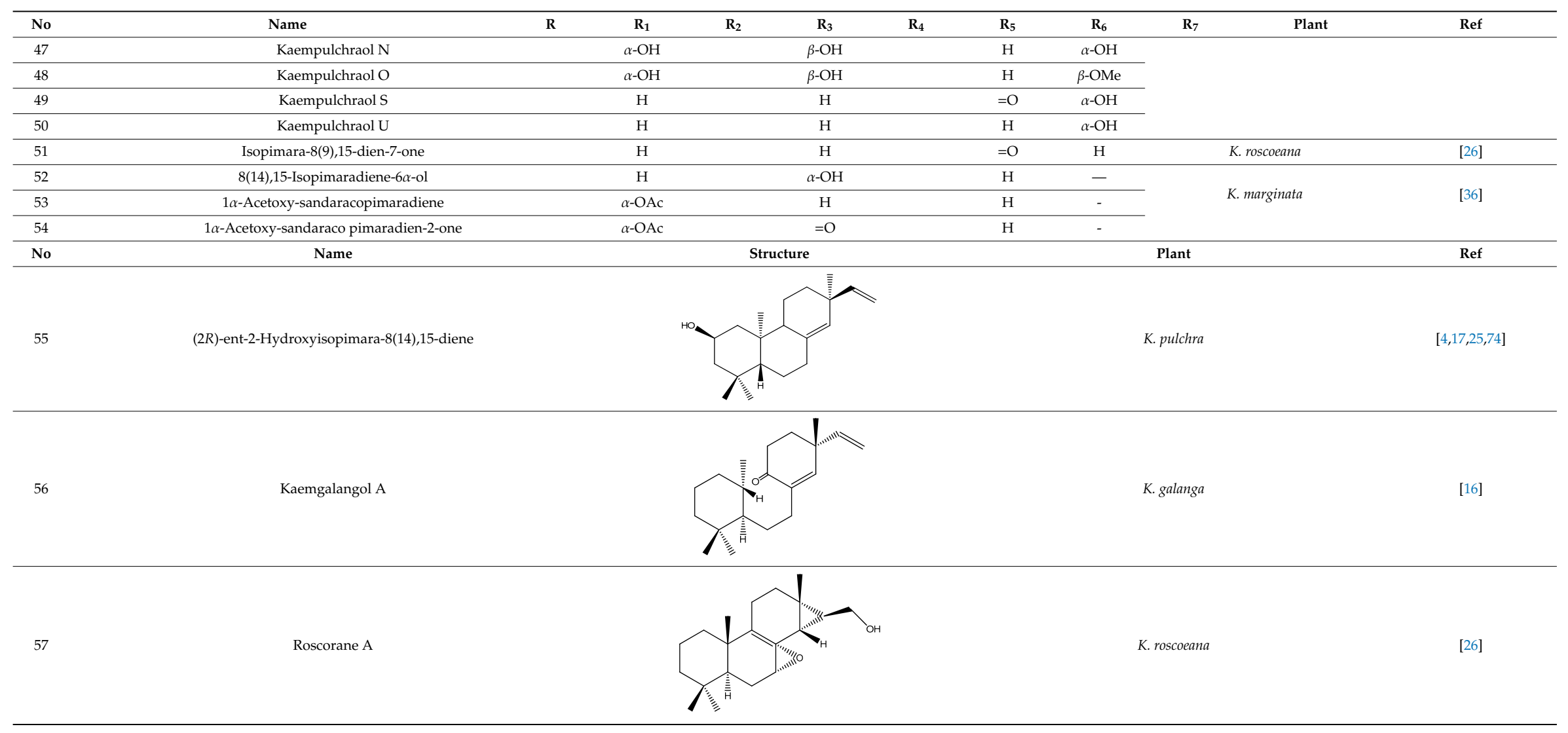


Table 1. Cont

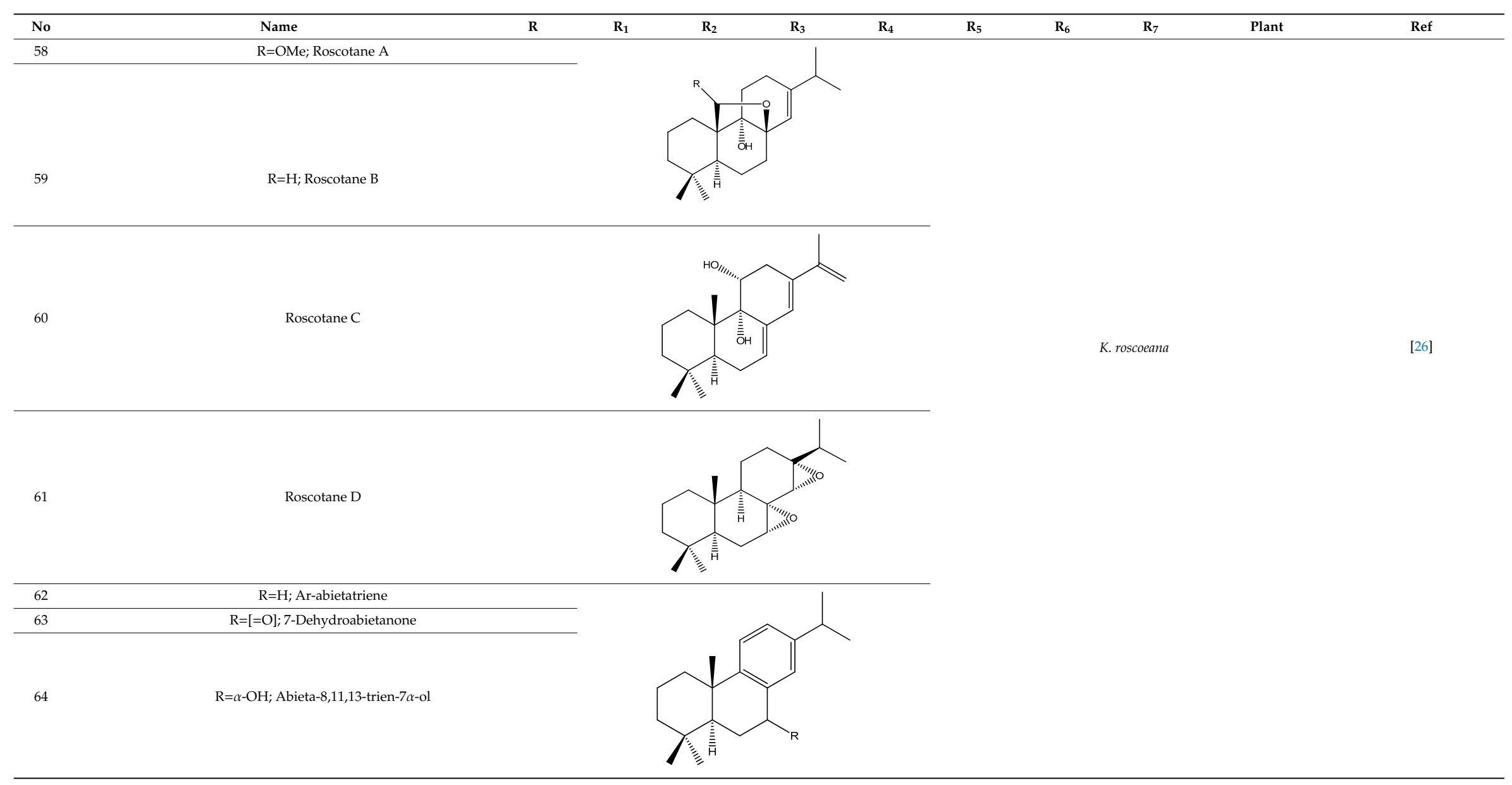


Table 1. Cont.

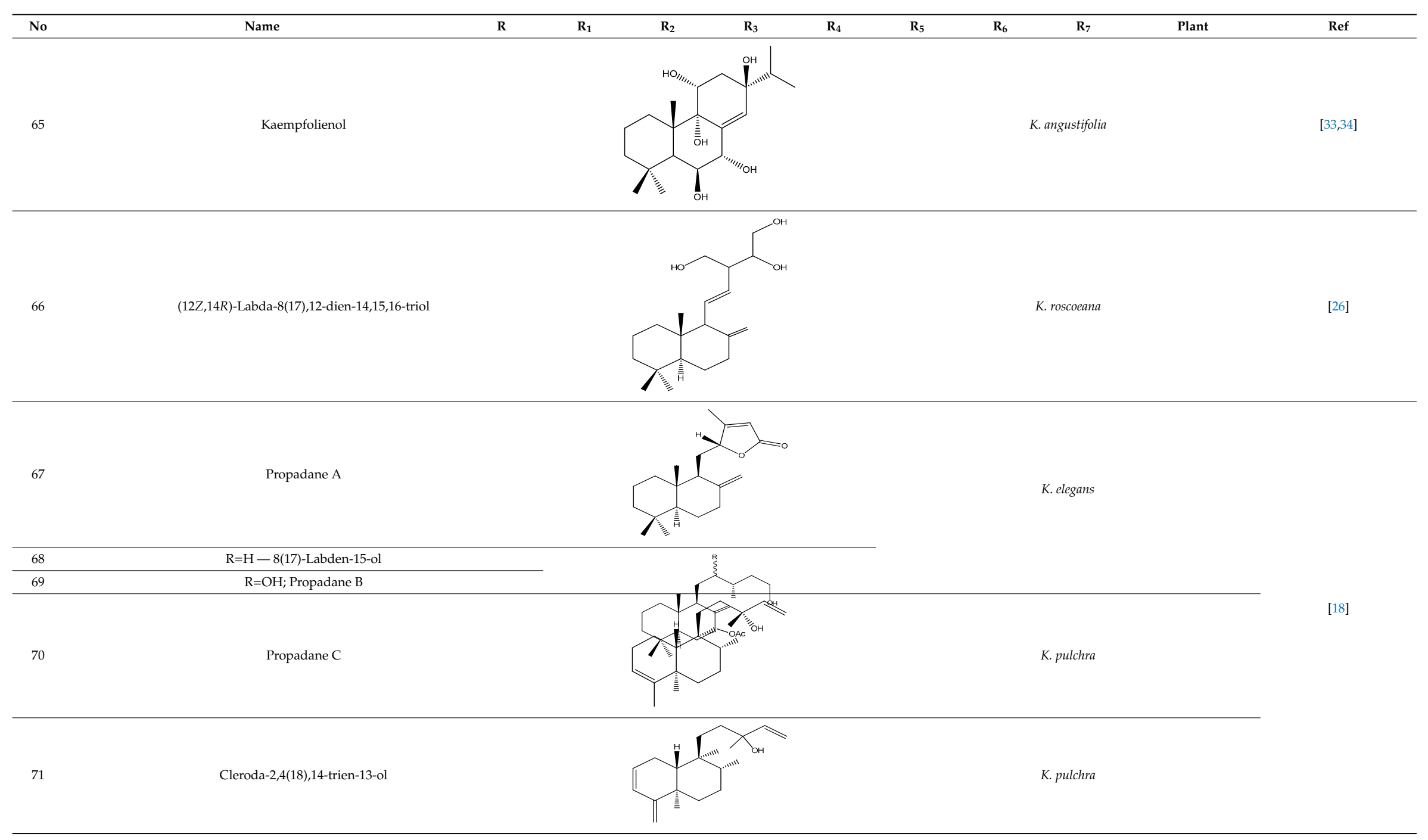


Nutrients 2019, 11, 2396

14 of 33

Table 1. Cont.

\begin{tabular}{ll}
\hline No & Name \\
\hline 72 & R=H; Anticopalic acid \\
\hline & \\
73 & R=Me; Methyl anticopalate
\end{tabular}

$\mathbf{R}_{2}$

$\mathbf{R}$

$\mathrm{R}_{1}$
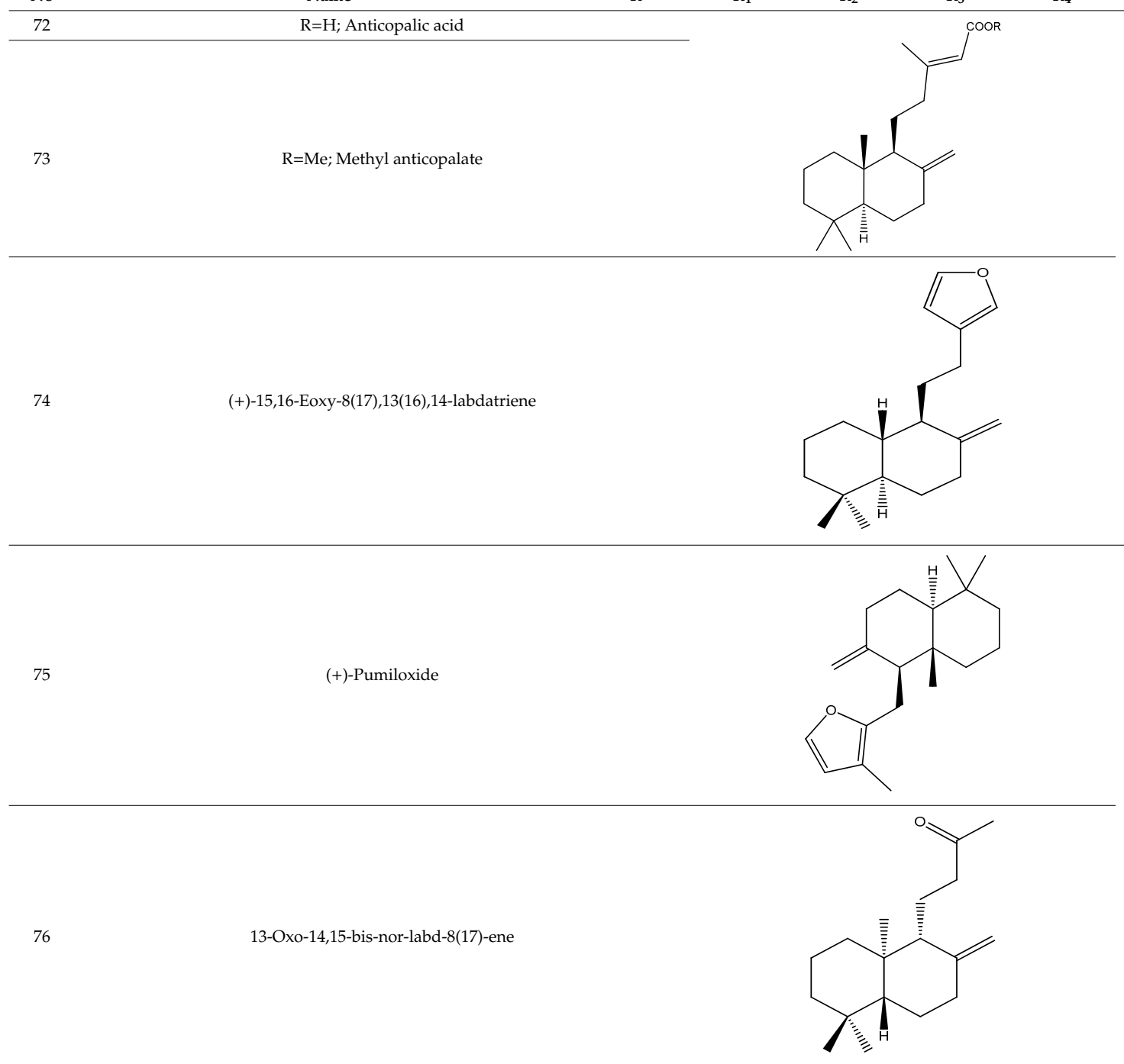

75

(+)-Pumiloxide
74

(+)-15,16-Eoxy-8(17),13(16),14-labdatriene

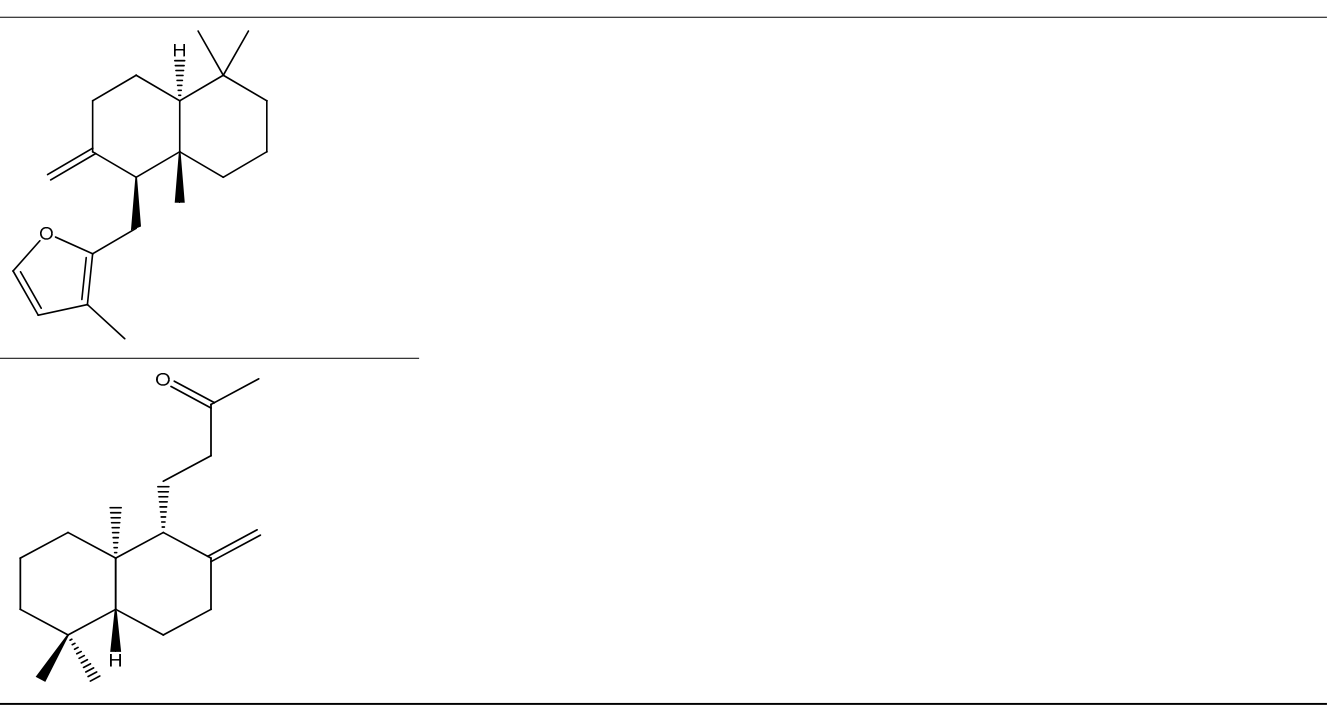

K. elegans

[18]

$\mathbf{R}_{5}$

$\mathbf{R}_{6}$

$\mathbf{R}_{7}$

Plant

Ref 
Table 1. Cont.

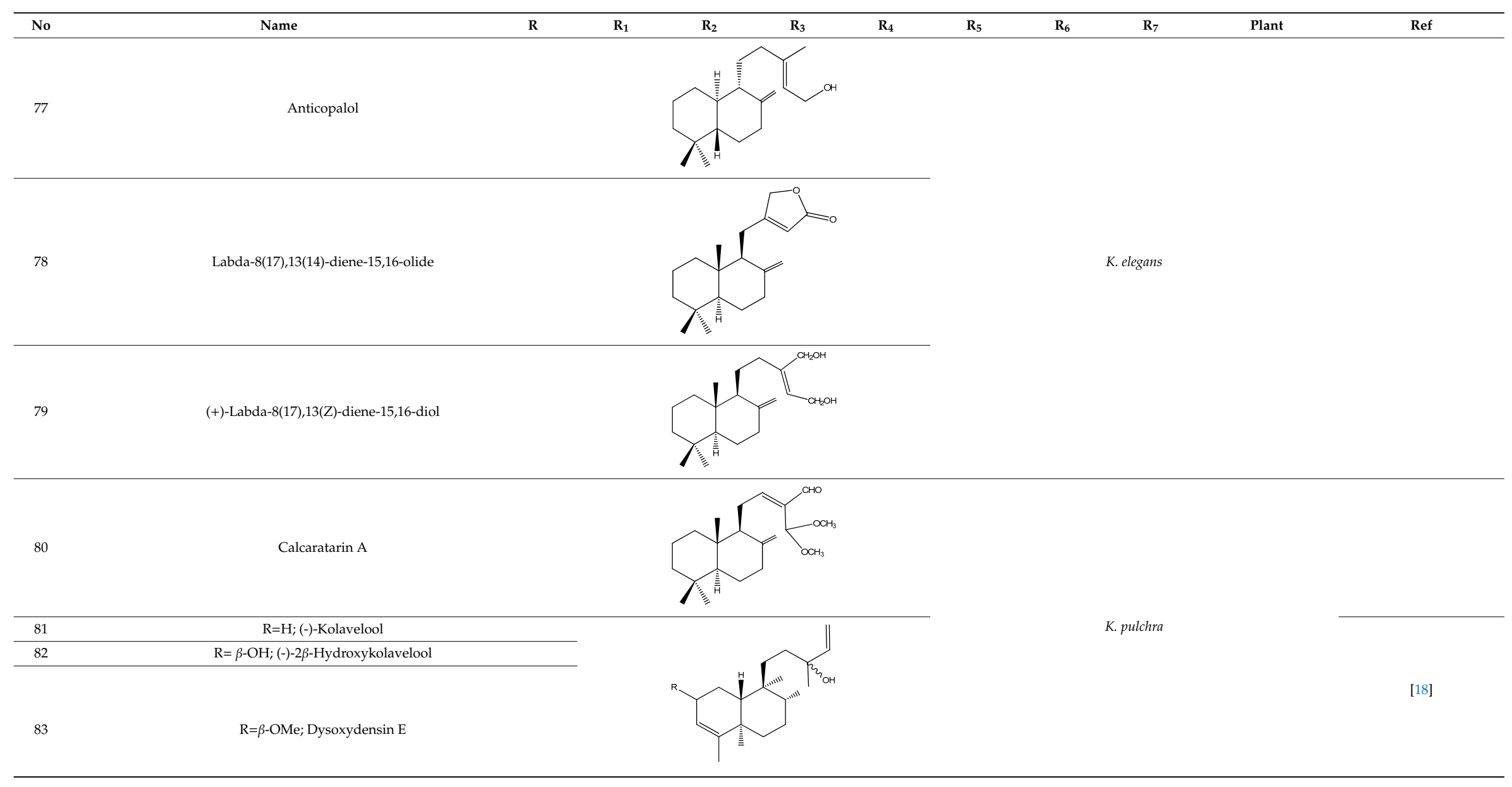


Nutrients 2019, 11, 2396

16 of 33

Table 1. Cont.

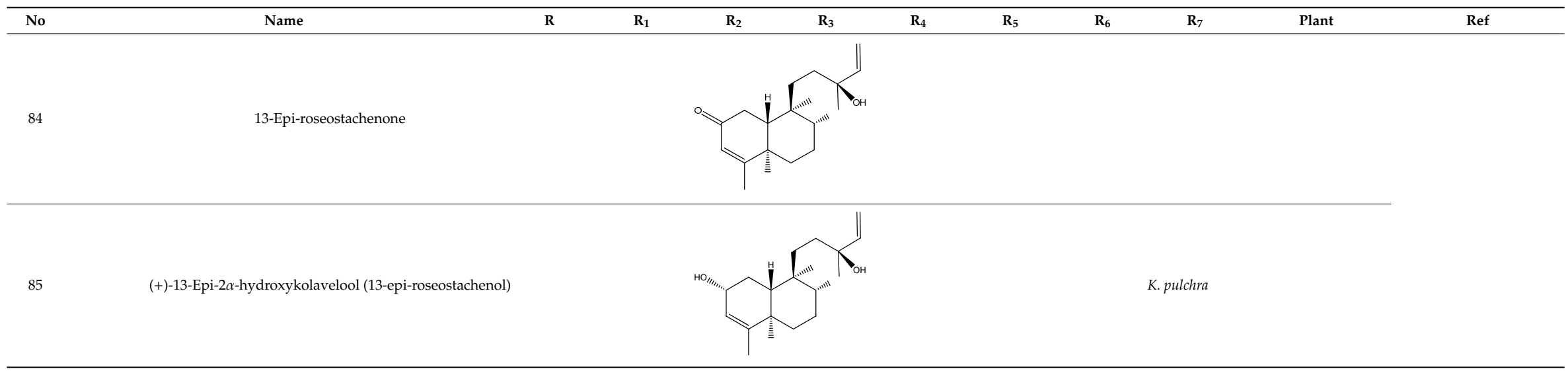


Table 2. Flavonoids and phenolics (Flavonoids).

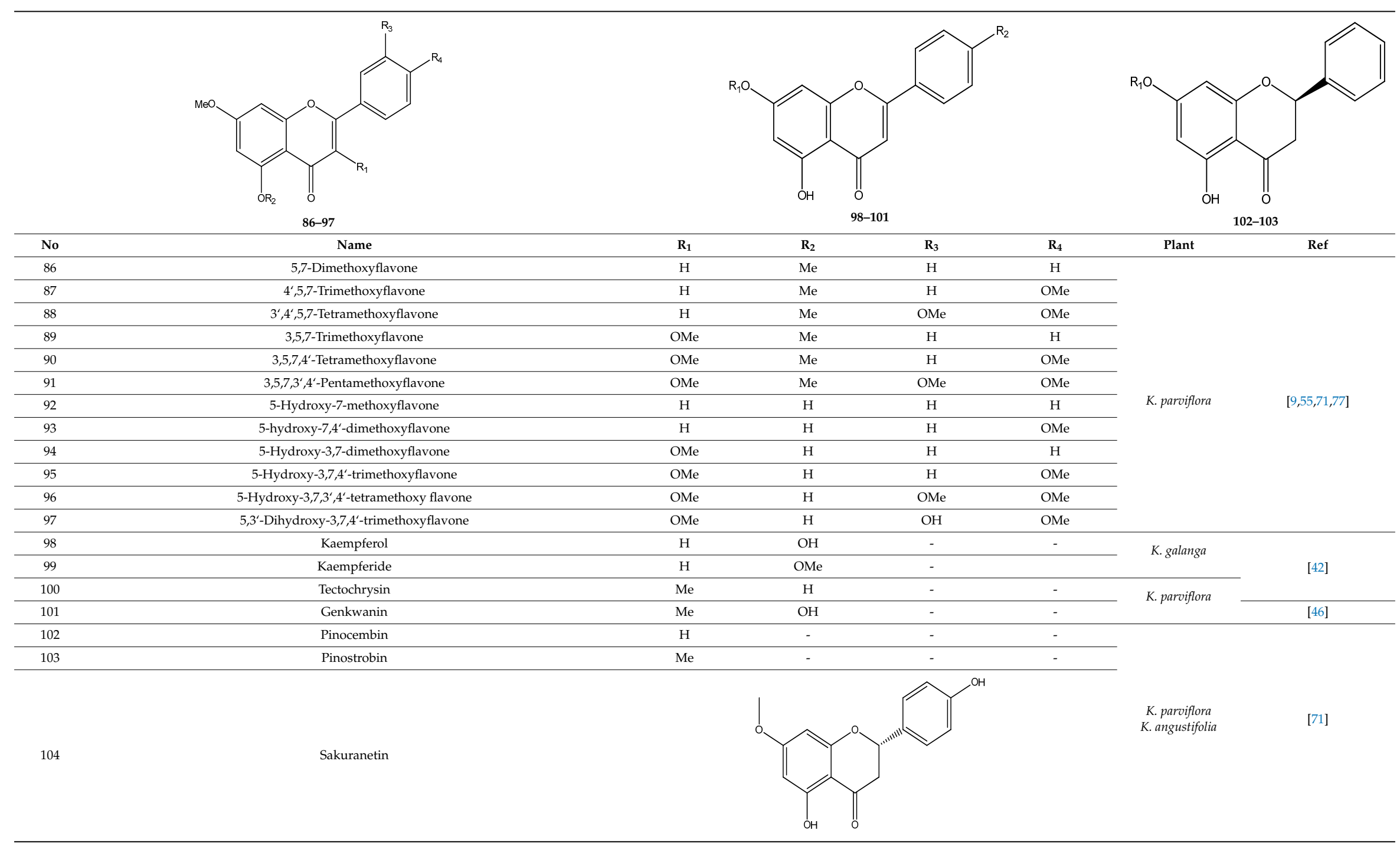


Table 2. Cont.

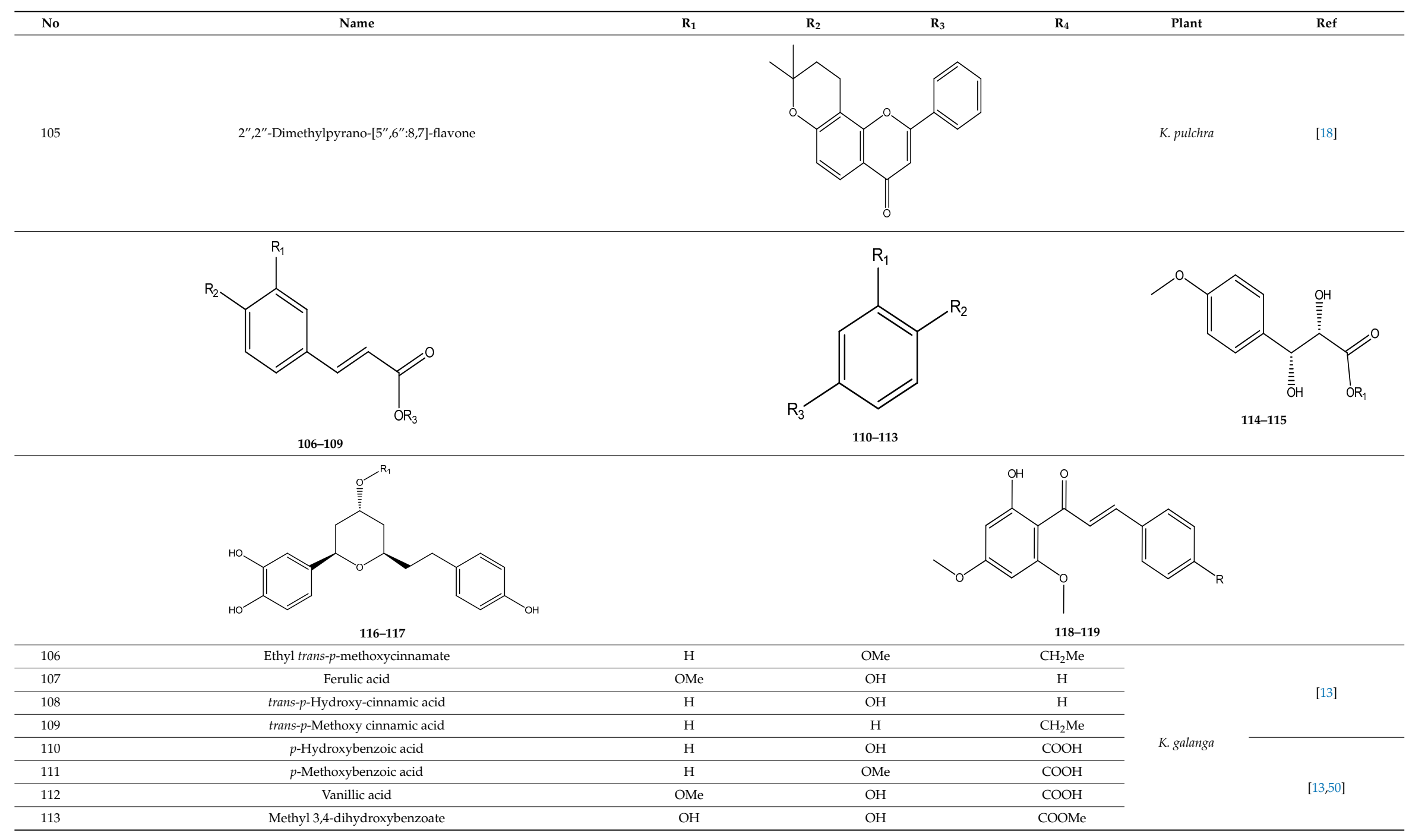


Table 2. Cont

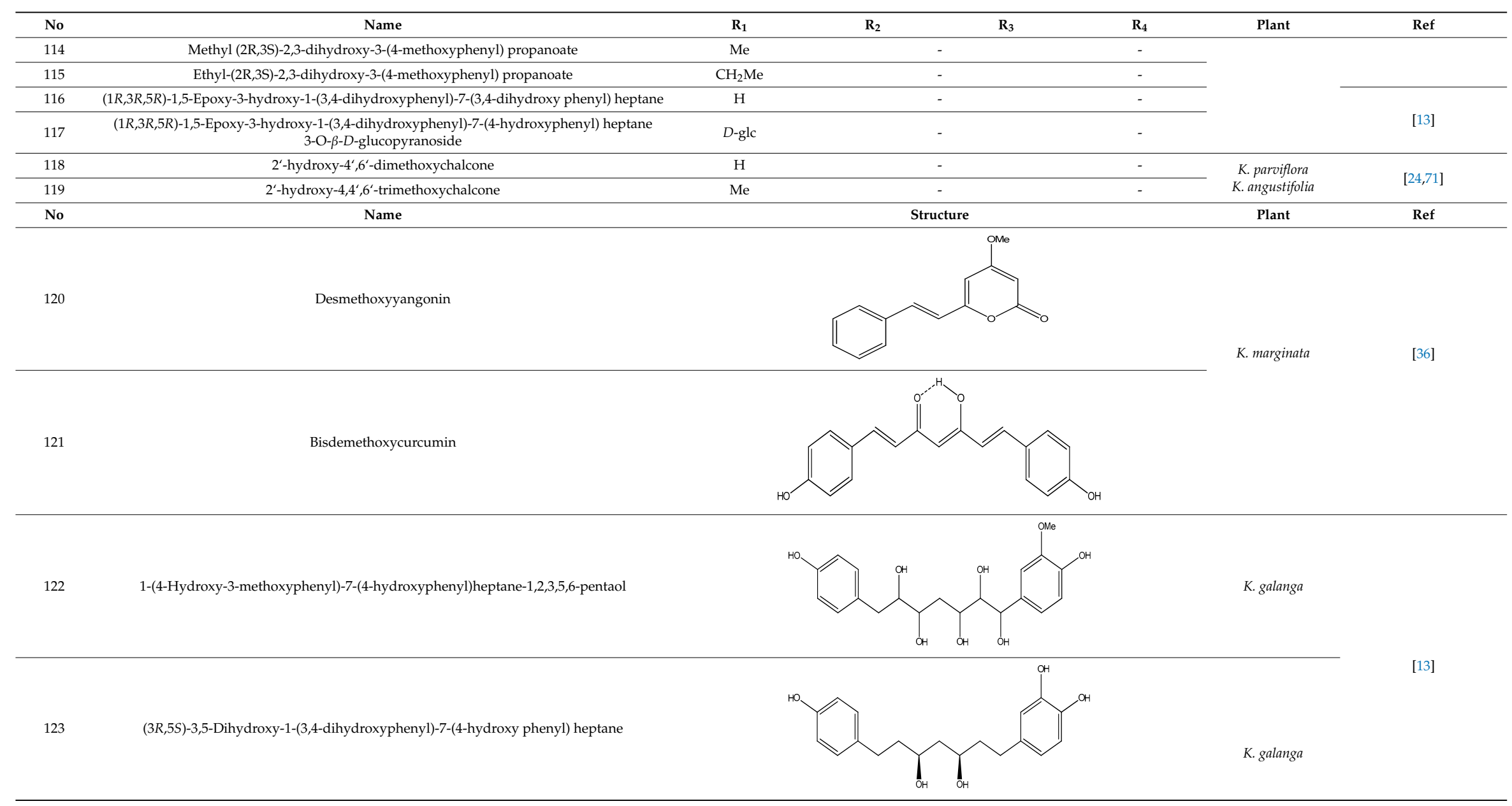


Nutrients 2019, 11, 2396

20 of 33

Table 2. Cont.

\begin{tabular}{ll}
\hline No & Name \\
\hline
\end{tabular}

124

Phaeoheptanoxide

125

Hedycoropyran B
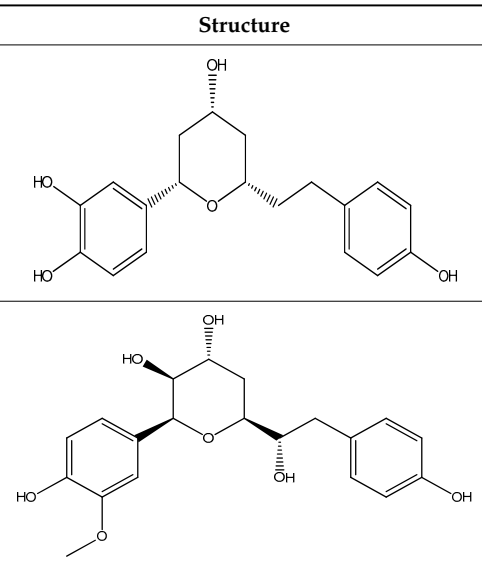

126

1-O-4-Carbonxylphenyl-(6-O-4-hydroxybenzoyl)- $\beta$ - $D$-glucopyranoside

127

Dihydro-5,6-dehydrokawain

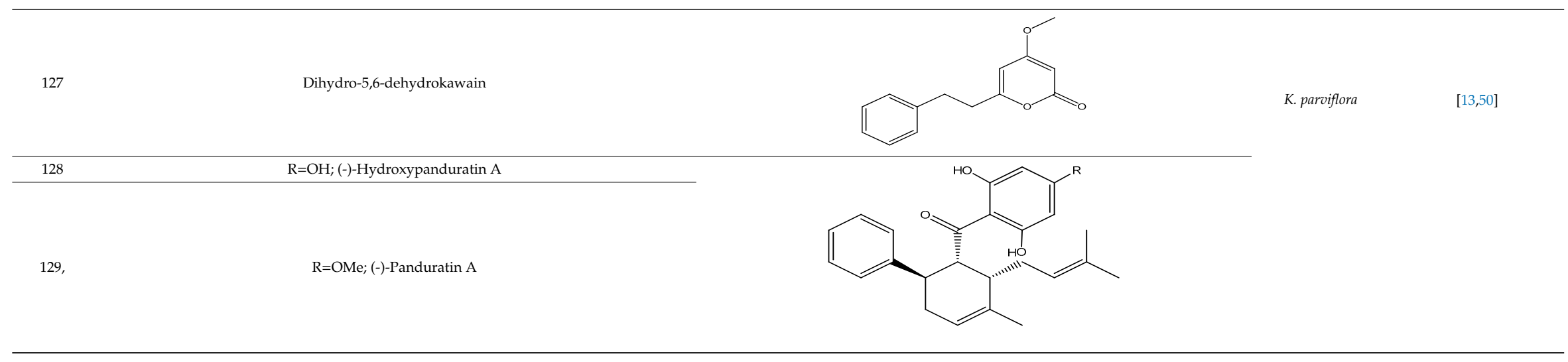

Plant

Ref

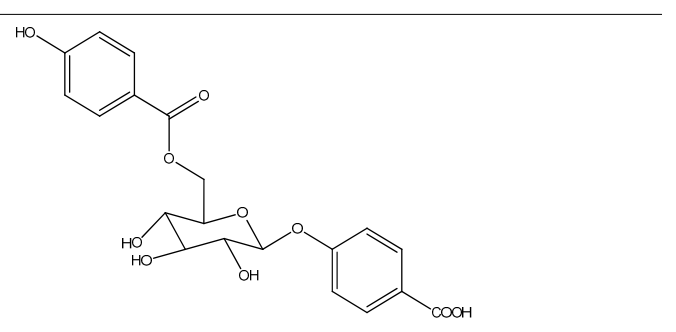


Table 2. Cont

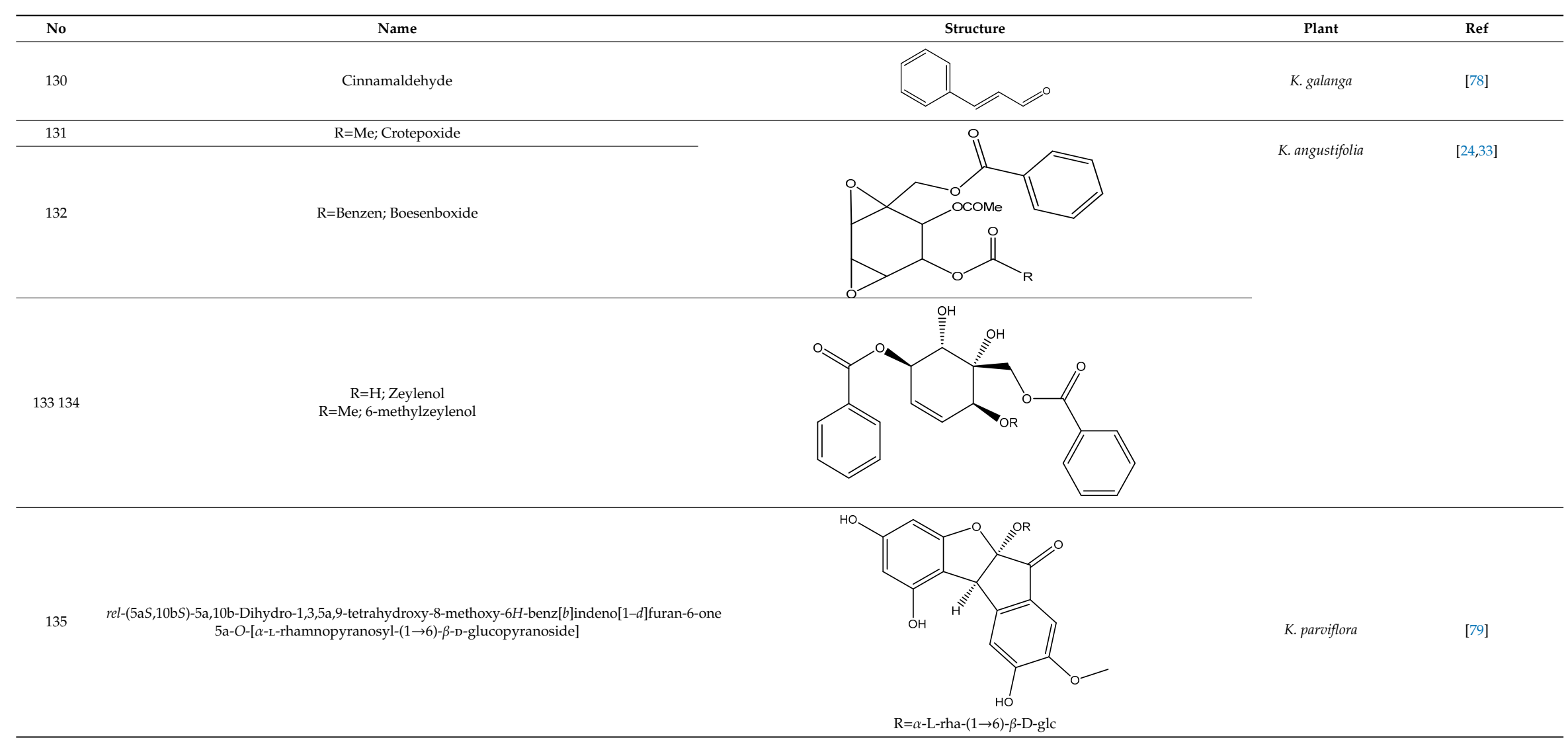


Table 2. Cont

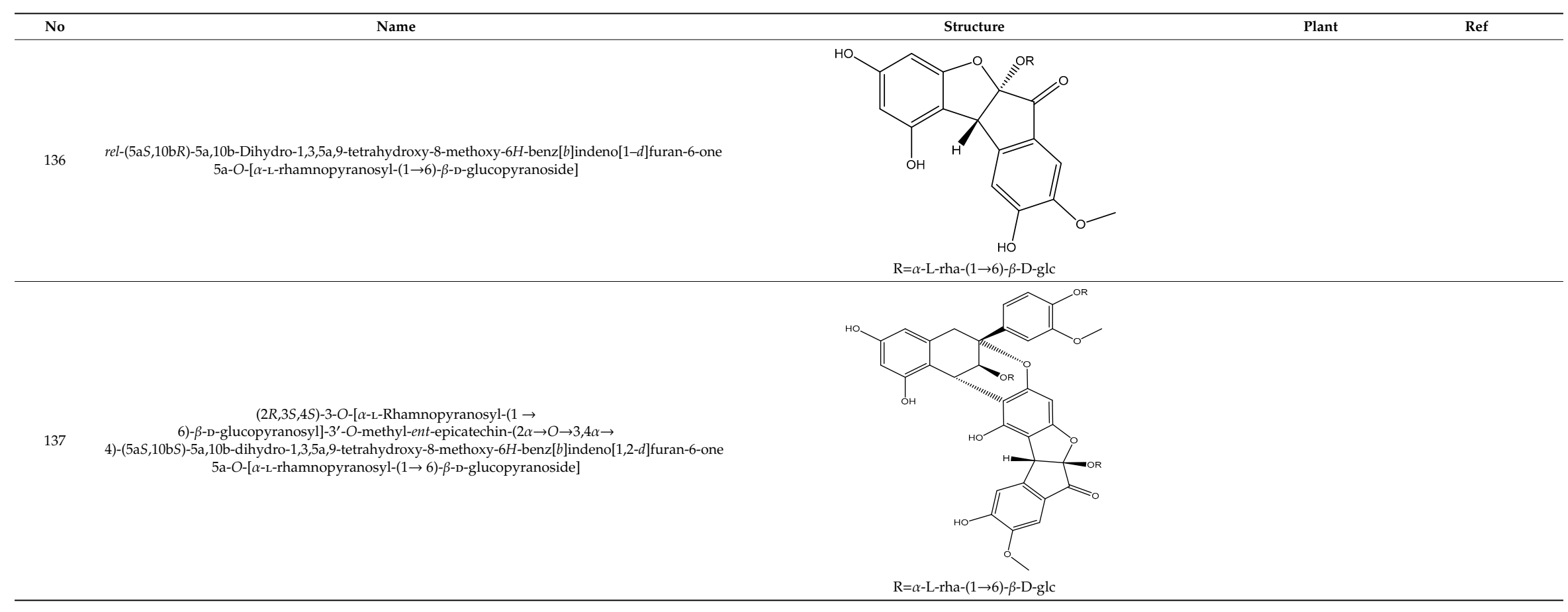


Table 3. Steroid and triterpenes.

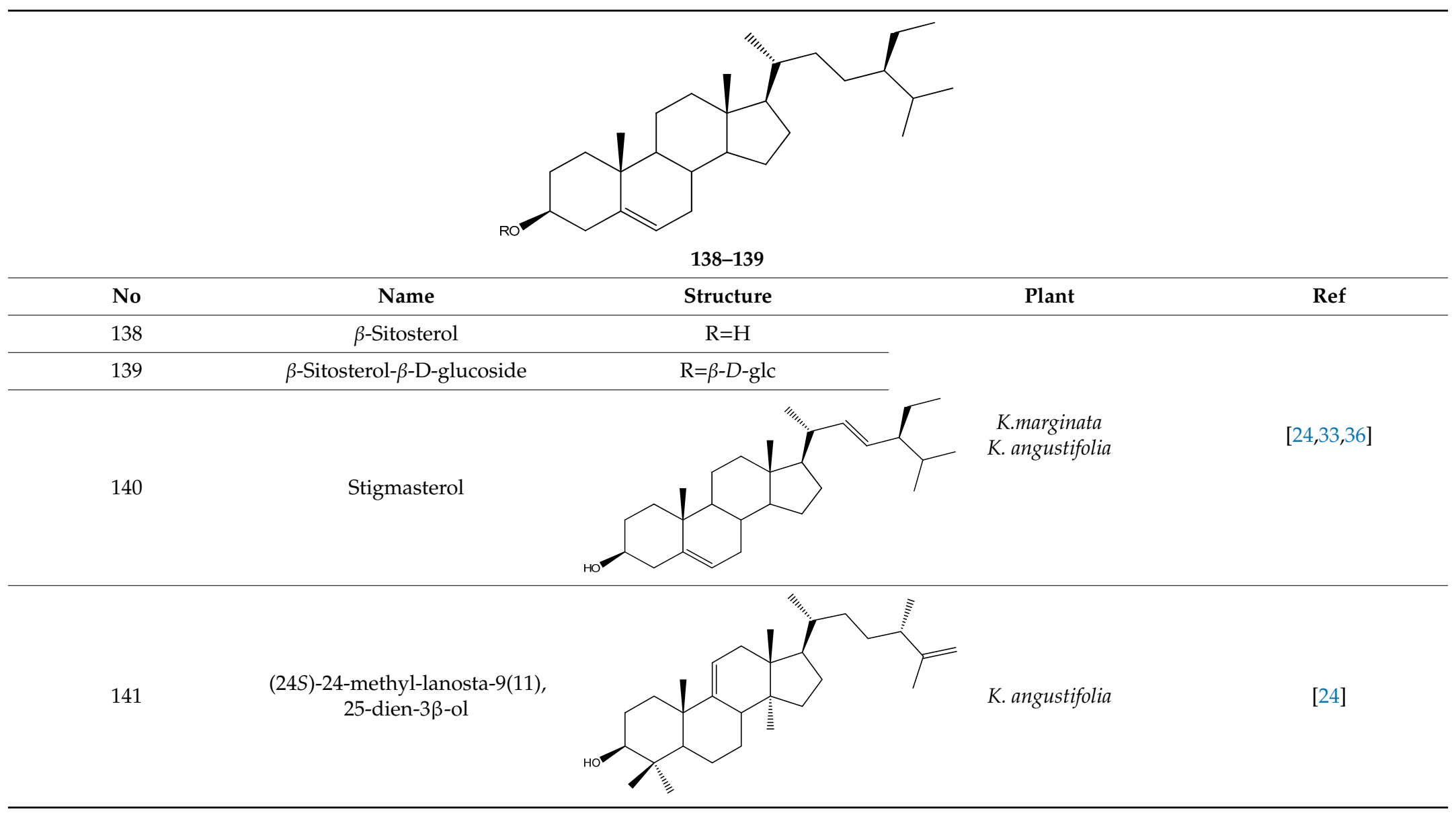




\subsection{Diterpenoids}

Kaempferia plants were characterized with a predominance of diterpenoids, especially the isopimaranes in addition to abietane, labdane, and clerodane types (Table 1).

\subsubsection{Isopimarane-Type Diterpenoids}

The isopimaranes reported from the Kaempheria species (Table 1) are characterized with the presence of two double bonds; one is mostly $\Delta^{15(16)}$, while the other is between $\Delta^{8(9)}$ or $\Delta^{8(14)}[4,25,74]$. From the rhizomes of $K$. galanga, 12 usual isopimarenes (1-8, 10, 11, 14, and 17) were observed that contained a $\Delta^{8(14), 15}$ motif in addition to the rarely reported oxygenated seco-isopimarane (56) [16]. From the rhizomes of $K$. marginata, five isopimarenes with a $\Delta^{8(14), 15}$ motif were observed (1, 2, 52-54) [36]. Only one thumbing isopimarenes, roscorane A (57), was reported from K. roscoeana, which was characterized by only one double bond $\Delta^{8(9)}$ and (7-8)-epoxy, as well as the absence of the exomethylene $\Delta^{15(16)}$ [26].

\section{Biosynthesis of Isopimarane-Type Diterpenoids}

Isopimarane diterpenoids are the most characteristic compounds for Kaempheria plants. $(E, E, E)$-Geranylgeranyl diphosphate (GGPP) is a well-known biosynthesized intermediate of diterpenoids as described by [80]. GGPP is firstly cyclized via copalyl diphosphate (CPP) synthases (CPS), and then by the unknown enzyme (PS), affording a charged intermediate (INM). Then, this intermediate is completely cyclized by the enzymatic reactions via the bifunctional (iso) pimaradiene synthases (AoCPS-PS, NfCPS-PS, and AfCPS-PS) (Scheme 1), as described by Xu et al. [81].

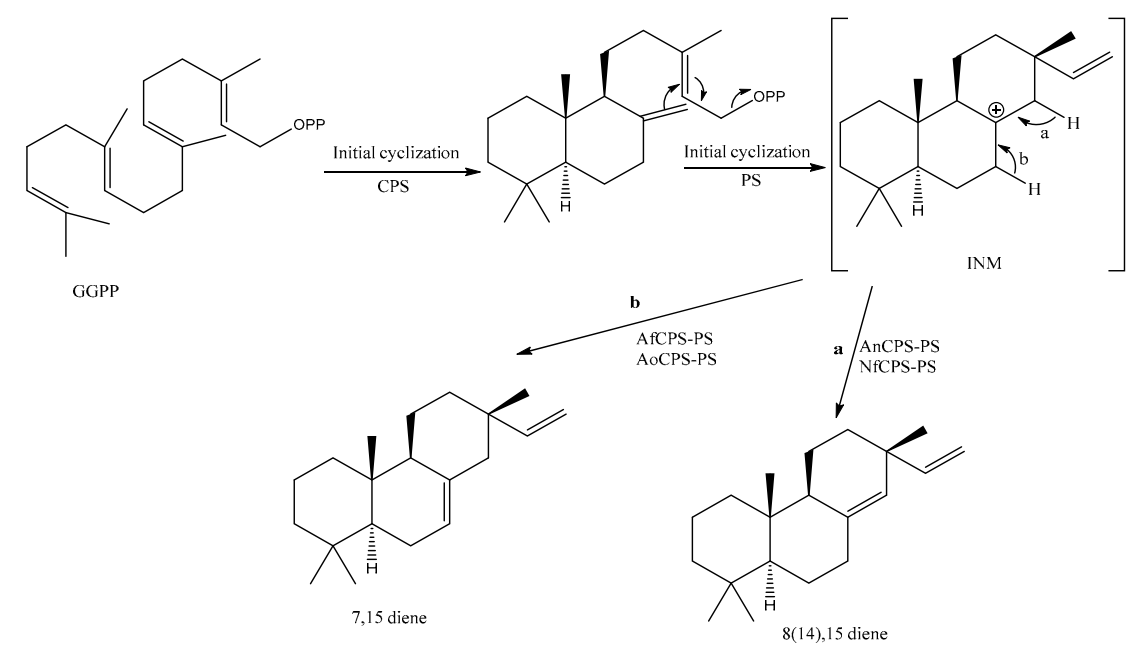

Scheme 1. Plausible isopimaradiene biosynthesis [81] starting with $(E, E, E)$-geranylgeranyl diphosphate (GGPP): (E,E,E)-geranylgeranyl diphosphate; CPS: copalyl diphosphate (CPP) synthases; PS: Unknown enzyme; AoCPS-PS, NfCPS-PS, and AfCPS-PS: bifunctional (iso) pimaradiene synthases.

\subsubsection{Abietane-Type Diterpenoids}

Seven abietanes (58-64) (Table 1) have been isolated and characterized from the rhizomes of K. roscoeana, and one (65) was isolated and characterized from K. angustifolia [26,33,34]. These highly oxygenated metabolites contain one or more double bonds and an absence of exomethylenes, except for roscotane D (61), which contains no double bonds.

\subsubsection{Labdane and Clerodane Diterpenoids}

After isopimarenes, labdane and clerodane represent major diterpenoid classes from the Kaempheria species. Nineteen highly oxygenated labdanes and clerodanes (66-86) have been reported from Kaempheria rhizomes (Table 1) [18,26]. From these isolated labdanes, only 
(12Z,14R)-labda-8(17),12-dien-14,15,16-triol (66) has been isolated from K. roscoeana rhizomes. In contrast, several labdane and clerodane types of diterpenoids have been isolated from K. elegans and K. pulchra rhizomes collected in Thailand.

\subsubsection{Flavonoids}

Kaempheria species are characterized by rich biological activity due in part to the presence of a diversity of flavonoids (86-105) and phenolic compounds (106-137) (Table 2). K. parviflora rhizomes with flavonoid nuclei contain methoxy groups in specific positions (86-97) $[9,55]$. Pyrano-flavone, 2",2"-dimethylpyrano-[5",6":8,7]-flavone (105), has been isolated from K. pulchra rhizomes collected from Thailand [18], and flavanones (97-99) have been isolated and identified from K. parviflora rhizomes [70,71]. K. galanga contains kaempferol and kaempferide $(\mathbf{9 8}, \mathbf{9 9})$ [78].

\subsubsection{Phenolic Compounds}

From K. galanga rhizomes, diarylheptanoid compounds $(116,117,122-125)$ are reported by Yao, Huang, Wang, and He [13]. From K. marginata rhizomes, curcuminoid (121) was characterized by Kaewkroek, Wattanapiromsakul, Kongsaeree, and Tewtrakul [36]. From K. galanga, rhizomes phenolic acids (106-113) were the major compounds isolated, including methoxylated cinnamic acid derivatives. Two (4-methoxyphenyl)-propanoates (114-115) were also isolated from the K. galanga rhizomes [13,50]. $S$ - and $R$-isomers at C-4 of phenolic glycosides (135 and 136) as well as a rare phenolic glycoside (137) were observed in K. previflora rhizomes [79]. All the phenolic compounds (106-137) are summarized in Table 2.

\subsubsection{Steroids and Triterpenes}

Steroids represent a minor class of compounds reported from Kaempheria species. Only three steroids, $\beta$-sitosterol (138), $\beta$-sitosterol- $\beta$-D-glucoside (139), and stigmasterol (140) (Table 3) have been reported from K. marginata rhizomes [36]. Moreover, only one lanostane type triterpene, (24S)-24-methyl-lanosta-9(11), 25-dien-3ß-ol (141), was isolated from K. angustifolia [24].

\subsubsection{Volatile Oils}

Kaempheria species were documented as very rich plants with volatile oils such as K. galanga $[29,73,82,83]$, K. angustiflora [29], and K. marginata [29]. The volatile oil of K. galanga has been reported as a potential market product in India and over all the world with market values around $600-700$ US $\$ / \mathrm{kg}$ on the international market [83]. Phenylpropanoids and/or cinamates were represented as major constituents of volatile oils derived from Kaempheria species followed by monoterpenes $[29,73,82]$. The phenylpropanoid compound, trans-ethyl cinnamate, was documented as a principal component of volatile oils of all the studied Kaempheria species up to date with concentrations varied from $16-35 \%$ of the total identified $[29,73,82,83]$. The volatile oils of Kaempheria species were reported to have numerous biological activities such as anti-microbial [83], antioxidant [35], nutraceutical [83], nematicidal toxicity [82], and larvicide activities [29]. Table 4 summarized the main components (142-157) of the reported volatile oils of Kaempheria species. 
Table 4. Main components of volatile oils of Kaempferia species.

\begin{tabular}{|c|c|c|c|}
\hline No & Name & Plant & Ref \\
\hline 142 & $\delta$-3-Carene & \multirow{16}{*}{ K. galanga } & \multirow{16}{*}[29,35,82,83]{} \\
\hline 143 & E-Ethyl cinnamate & & \\
\hline 144 & Ethyl-p-methoxycinnamate & & \\
\hline 145 & $\gamma$-Cadinene & & \\
\hline 146 & 1,8-Cineole & & \\
\hline 147 & Trans-cinnamaldehyde & & \\
\hline 148 & Borneol & & \\
\hline 149 & Pentadecane & & \\
\hline 150 & $\gamma$-car-3-ene & & \\
\hline 151 & Linoleoyl chloride & & \\
\hline 152 & Caryophyllene oxide & & \\
\hline 153 & Cubenol & & \\
\hline 154 & Caryophyllene & & \\
\hline 155 & Limonene & & \\
\hline 156 & Camphene & & \\
\hline 157 & $\alpha$-Pinene & & \\
\hline
\end{tabular}

\section{Principal Components Analysis (PCA) and Agglomerative Hierarchical Clustering (AHC) for Kaempferia Species}

To assess the correlation between the various Kaempferia species, chemical classes of different compounds were subjected to PCA and AHC (Figure 3). According to the similarity, the analysis showed that we can group the Kaempferia species under three groups: the first group comprised K. galanga, K. marginata, K. pulchra, and K. roscoeana, and these species are correlated to isopimaranes compounds. The Pearson correlation coefficient (r) between K. marginata and K. pulchra was the highest with $\mathrm{r}=0.938$, while between $K$. marginata and $K$. roscoeana, it was 0.771 , between $K$. roscoeana and K. pulchra, it was 0.766, and between K. marginata and K. galanga, it was 0.615 (Table 5).

Table 5. Proximity matrix (Pearson correlation coefficient) of the seven Kaempferia species based on the chemical classes reported.

\begin{tabular}{ccccccc}
\hline & K. angustifolia & K. elegans & K. galanga & K. marginata & K. parviflora & K. pulchra \\
\hline K. elegans & -0.539 & & & & & \\
K. galanga & -0.042 & -0.339 & & & & \\
K. marginata & -0.500 & -0.241 & 0.615 & & & \\
K. parviflora & 0.833 & -0.312 & 0.075 & -0.280 & & \\
K. pulchra & -0.675 & 0.053 & 0.378 & 0.938 & -0.372 & 0.766 \\
K. roscoeana & -0.643 & -0.225 & 0.206 & 0.771 & -0.513 & 0.76 \\
\hline
\end{tabular}

The second group contained K. angustifolia and K. parviflora $(\mathrm{r}=0.833)$, and this group showed a close correlation to flavonoids and phenolics. However, the K. elegans was separated alone, and showed a close relation to labdane and clerodane compounds. The similarities within each group might be ascribed to the genetic relations, as well as the environmental and microclimatic conditions [1-3].

In a study of a genetic variation of Kaempferia species based on chloroplast DNA [5], K. marginata and K. galanga were grouped together, which is agreeable with our results $(r=0.615)$ according to the PCA data of the present study based on the chemical composition. However, in contrast to the data from the PCA, K. angustifolia and K. parviflora were separated in different groups, but K. elegans and 
K. parviflora were grouped together. In another recent study, based on the DNA and morphological characteristics [84], K. angustifolia and K. parviflora were grouped together in agreement with the chemical variation of the present study.
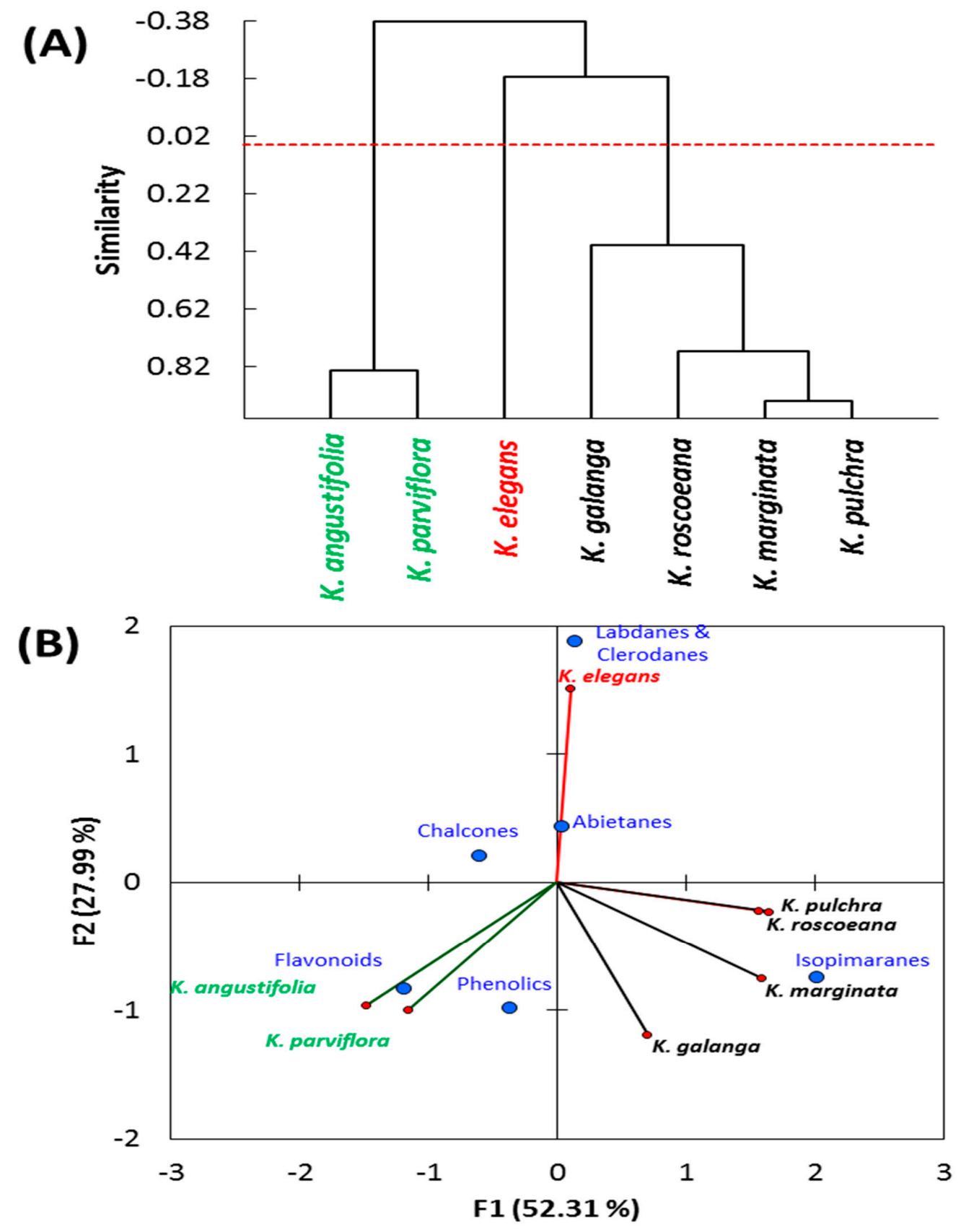

Figure 3. (A) Agglomerative hierarchical clustering (AHC) and (B) Principal component analysis (PCA) based on the chemical composition of different chemical classes of seven Kaempferia species (K. angustifolia, K. elegans, K. galanga, K. marginata, K. parviflora, K. pulchra, and K. roscoeana).

\section{Conclusions}

Kaempheria species are widely used plants in traditional medicine worldwide. All the biological activity data for these plants and their isolated constituents have resulted in numerous leads for medicinal drugs. Mainly, seven rhizomes of Kaempheria plants afforded a vast array of diterpenoids, especially the isopimarane type, along with significant bioactive methoxylated flavonoids. From all 
these documented chemical and biological results, these plants have been and continue to be a promising source for medicinal natural products and food industrial products.

Author Contributions: A.I.E., T.A.M. and M.-E.F.H. suggested and designed the study. A.I.E., T.A.M., A.F.E., and A.M.A.-E.G. did the data preparation and structure drawing. A.I.E., T.A.M., A.M.A.-E.G., and M.-E.F.H. collected the data. A.S.A., A.A.S., T.Y., A.R.H.F., and M.N. wrote the original manuscript. A.I.E., T.A.M., M.-E.F.H., P.W.P., A.U., A.S.A., A.A.S., and H.R.E.-S. edited the final manuscript. All the authors reviewed and approved the manuscript.

Funding: This research received no external funding.

Acknowledgments: The authors are thankful to the Deanship of the Scientific Research and Research Center, College of Pharmacy, King Saud University, Riyadh, Saudi Arabia. Dr. Elshamy gratefully acknowledges the Takeda Science Foundation, Japan for financial support. Prof. Mohamed Hegazy gratefully acknowledges the financial support from Alexander von Humboldt Foundation "Georg Foster Research Fellowship for Experienced Researcher".

Conflicts of Interest: The authors declare no conflict of interest.

\section{Abbreviations}

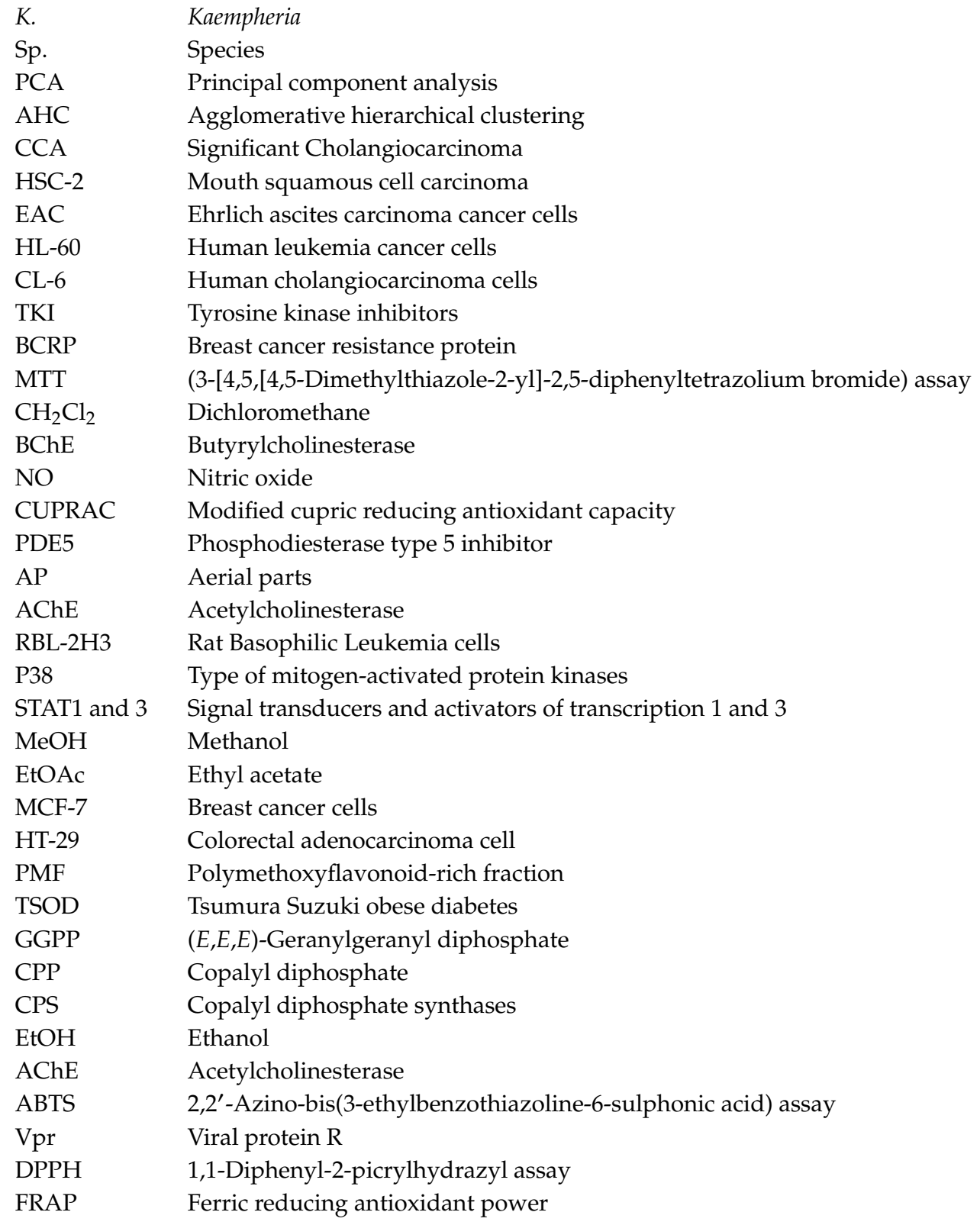




$\begin{array}{ll}\text { CYP3A } & \text { Cytochrome P450, family 3, subfamily A } \\ \text { NF- } \mathrm{B} & \text { Nuclear factor pathway } \\ \text { Rh } & \text { Rhizomes } \\ \text { BChE } & \text { Butyrylcholinesterase } \\ \text { STZ } & \text { Streptozotocin } \\ \text { MPO } & \text { myeloperoxidase } \\ \text { DMF } & \text { Dimethylformamide } \\ \text { MAPKs } & \text { Type of mitogen-activated protein kinases } \\ \text { PGE2 } & \text { Prostaglandin E2 }\end{array}$

\section{References}

1. Vinceti, B.; Loo, J.; Gaisberger, H.; van Zonneveld, M.J.; Schueler, S.; Konrad, H.; Kadu, C.A.; Geburek, T. Conservation priorities for Prunus africana defined with the aid of spatial analysis of genetic data and climatic variables. PLoS ONE 2013, 8, e59987. [CrossRef] [PubMed]

2. Pérez-Sánchez, R.; Gálvez, C.; Ubera, J.L. Bioclimatic influence on essential oil composition in South Iberian Peninsular populations of Thymus zygis. J. Essent. Oil Res. 2012, 24, 71-81. [CrossRef]

3. Elshamy, A.; Mohamed, T.A.; Al-Rowaily, S.L.; Abd El-Gawad, A.M.; Dar, B.A.; Shahat, A.A.; Hegazy, M.F. Euphosantianane E-G: Three new premyrsinane type 2 diterpenoids from Euphorbia sanctae-catharinae with 3 contribution to chemotaxonomy. Molecules 2019, 24, 2412. [CrossRef] [PubMed]

4. Ekor, M. The growing use of herbal medicines: Issues relating to adverse reactions and challenges in monitoring safety. Front Pharmacol. 2013, 4, 177. [CrossRef] [PubMed]

5. Techaprasan, J.; Klinbunga, S.; Ngamriabsakul, C.; Jenjittikul, T. Genetic variation of Kaempferia (Zingiberaceae) in Thailand based on chloroplast DNA (psbA-trnH and petA-psbJ) sequences. Genet. Mol. Res. 2010, 9, 1957-1973. [CrossRef]

6. Wutythamawech, W. Encyclopedia of Thai Herbs; OS Printing: Bangkok, Thailand, 1997; p. 365.

7. Yenjai, C.; Prasanphen, K.; Daodee, S.; Wongpanich, V.; Kittakoop, P. Bioactive flavonoids from Kaempferia parviflora. Fitoterapia 2004, 75, 89-92. [CrossRef]

8. Akase, T.; Shimada, T.; Terabayashi, S.; Ikeya, Y.; Sanada, H.; Aburada, M. Antiobesity effects of Kaempferia parviflora in spontaneously obese type II diabetic mice. J. Nat. Med. 2011, 65, 73-80. [CrossRef]

9. Nakao, K.; Murata, K.; Deguchi, T.; Itoh, K.; Fujita, T.; Higashino, M.; Yoshioka, Y.; Matsumura, S.-I.; Tanaka, R.; Shinada, T. Xanthine oxidase inhibitory activities and crystal structures of methoxyflavones from Kaempferia parviflora rhizome. Biol. Pharm. Bull. 2011, 34, 1143-1146. [CrossRef]

10. Sivarajan, V.; Balachandran, I. Ayurvedic Drugs and their Plant Sources Oxford and IBH Publishing Co; Oxford \& IBH Pub. Co: New Delhi, India, 1994.

11. Hidaka, M.; Horikawa, K.; Akase, T.; Makihara, H.; Ogami, T.; Tomozawa, H.; Tsubata, M.; Ibuki, A.; Matsumoto, Y. Efficacy of Kaempferia parviflora in a mouse model of obesity-induced dermatopathy. J. Nat. Med. 2017, 71, 59-67. [CrossRef]

12. Win, N.N.; Ito, T.; Matsui, T.; Aimaiti, S.; Kodama, T.; Ngwe, H.; Okamoto, Y.; Tanaka, M.; Asakawa, Y.; Abe, I. Isopimarane diterpenoids from Kaempferia pulchra rhizomes collected in Myanmar and their Vpr inhibitory activity. Bioorganic Med. Chem. Lett. 2016, 26, 1789-1793. [CrossRef]

13. Yao, F.; Huang, Y.; Wang, Y.; He, X. Anti-inflammatory diarylheptanoids and phenolics from the rhizomes of kencur (Kaempferia galanga L.). Ind. Crop. Prod. 2018, 125, 454-461. [CrossRef]

14. Vimala, S.; Norhanom, A.; Yadav, M. Anti-tumour promoter activity in Malaysian ginger rhizobia used in traditional medicine. Br. J. Cancer 1999, 80, 110. [CrossRef] [PubMed]

15. Amuamuta, A.; Plengsuriyakarn, T.; Na-Bangchang, K.J. Anticholangiocarcinoma activity and toxicity of the Kaempferia galanga Linn. rhizome ethanolic extract. BMC Complementary Altern. Med. 2017, 17, 213. [CrossRef] [PubMed]

16. Swapana, N.; Tominaga, T.; Elshamy, A.I.; Ibrahim, M.A.; Hegazy, M.-E.F.; Singh, C.B.; Suenaga, M.; Imagawa, H.; Noji, M.; Umeyama, A. Kaemgalangol A: Unusual seco-isopimarane diterpenoid from aromatic ginger Kaempferia galanga. Fitoterapia 2018, 129, 47-53. [CrossRef] [PubMed] 
17. Win, N.N.; Ito, T.; Aimaiti, S.; Kodama, T.; Imagawa, H.; Ngwe, H.; Asakawa, Y.; Abe, I.; Morita, H. Kaempulchraols I-O: New isopimarane diterpenoids from Kaempferia pulchra rhizomes collected in Myanmar and their antiproliferative activity. Tetrahedron 2015, 71, 4707-4713. [CrossRef]

18. Chawengrum, P.; Boonsombat, J.; Kittakoop, P.; Mahidol, C.; Ruchirawat, S.; Thongnest, S. Cytotoxic and antimicrobial labdane and clerodane diterpenoids from Kaempferia elegans and Kaempferia pulchra. Phytochem. Lett 2018, 24, 140-144. [CrossRef]

19. Dash, P.R.; Nasrin, M.; Ali, M.S. In vivo cytotoxic and In vitro antibacterial activities of Kaempferia galanga. J. Pharmacogn. Phytochem. 2014, 3, 172-177.

20. Ali, H.; Yesmin, R.; Satter, M.A.; Habib, R.; Yeasmin, T. Antioxidant and antineoplastic activities of methanolic extract of Kaempferia galanga Linn. Rhizome against Ehrlich ascites carcinoma cells. J. King Saud Univ. Sci. 2018, 30, 386-392. [CrossRef]

21. Bae, S.; D'cunha, R.; Shao, J.; An, G. Effect of 5, 7-dimethoxyflavone on Bcrp1-mediated transport of sorafenib in vitro and in vivo in mice. Eur. J. Pharm. Sci. 2018, 117, 27-34. [CrossRef]

22. Ahmed, F.R.S.; Amin, R.; Hasan, I.; Asaduzzaman, A.; Kabir, S.R. Antitumor properties of a methyl- $\beta$-d-galactopyranoside specific lectin from Kaempferia rotunda against Ehrlich ascites carcinoma cells. Int. J. Biol. Macromol. 2017, 102, 952-959. [CrossRef]

23. Omar, M.N.; Rahman, S.A.; Ichwan, S.; Hasali, N.; Rasid, F.A.; Halim, F.A. Cytotoxicity effects of extracts and essential oil of Kaempferia galanga on cervical cancer C33A cell line. Orient. J. Chem. 2017, 33, 1659-1664. [CrossRef]

24. Tang, S.W.; Sukari, M.A.; Neoh, B.K.; Yeap, Y.S.Y.; Abdul, A.B.; Kifli, N.; Cheng Lian Ee, G. Phytochemicals from Kaempferia angustifolia Rosc. and their cytotoxic and antimicrobial activities. Biomed Res. Int. 2014, 2014. [CrossRef] [PubMed]

25. Win, N.N.; Ngwe, H.; Abe, I.; Morita, H. Naturally occurring Vpr inhibitors from medicinal plants of Myanmar. J. Nat. Med. 2017, 71, 579-589. [CrossRef] [PubMed]

26. Boonsombat, J.; Mahidol, C.; Chawengrum, P.; Reuk-Ngam, N.; Chimnoi, N.; Techasakul, S.; Ruchirawat, S.; Thongnest, S. Roscotanes and roscoranes: Oxygenated abietane and pimarane diterpenoids from Kaempferia roscoeana. Phytochemistry 2017, 143, 36-44. [CrossRef]

27. Lakshmanan, D.; Werngren, J.; Jose, L.; Suja, K.; Nair, M.S.; Varma, R.L.; Mundayoor, S.; Hoffner, S.; Kumar, R.A. Ethyl $p$-methoxycinnamate isolated from a traditional anti-tuberculosis medicinal herb inhibits drug resistant strains of Mycobacterium tuberculosis in vitro. Fitoterapia 2011, 82, 757-761. [CrossRef]

28. Yang, Y.; Tian, S.; Wang, F.; Li, Z.; Liu, L.; Yang, X.; Bao, Y.; Wu, Y.; Huang, Y.; Sun, L. Chemical composition and antibacterial activity of Kaempferia galanga essential oil. Int. J. Agric. Biol. 2018, 20, 457-462. [CrossRef]

29. Panyakaew, J.; Sookkhee, S.; Rotarayanont, S.; Kittiwachana, S.; Wangkarn, S.; Mungkornasawakul, P. Chemical variation and potential of Kaempferia oils as larvicide against Aedes aegypti. J. Essent. Oil Bear. Plants 2017, 20, 1044-1056. [CrossRef]

30. Malahayati, N.; Widowati, T.W.; Febrianti, A. Total phenolic, antioxidant and antibacterial activities of curcumin extract of kunci pepet (Kaempferia rotunda L). Res. J. Pharm. Biol. Chem. Sci. 2018, 9, 129-135.

31. Fauziyah, P.N.; Sukandar, E.Y.; Ayuningtyas, D.K. Combination effect of antituberculosis drugs and ethanolic extract of selected medicinal plants against multi-drug resistant Mycobacterium tuberculosis isolates. Sci. Pharm. 2017, 85, 14. [CrossRef]

32. Kochuthressia, K.; Britto, S.J.; Jaseentha, M.; Raphael, R. In vitro antimicrobial evaluation of Kaempferia galanga L. rhizome extract. Am. J. Biotechnol. Mol. Sci. 2012, 2, 1-5. [CrossRef]

33. Yeap, Y.S.Y.; Kassim, N.K.; Ng, R.C.; Ee, G.C.L.; Saiful Yazan, L.; Musa, K.H. Antioxidant properties of ginger (Kaempferia angustifolia Rosc.) and its chemical markers. Int. J. Food Prop. 2017, 20, 1158-1172. [CrossRef]

34. Tang, S.W.; Sukari, M.A.; Rahmani, M.; Lajis, N.H.; Ali, A.M. A new abietene diterpene and other constituents from Kaempferia angustifolia Rosc. Molecules 2011, 16, 3018-3028. [CrossRef] [PubMed]

35. Sahoo, S.; Parida, R.; Singh, S.; Padhy, R.N.; Nayak, S. Evaluation of yield, quality and antioxidant activity of essential oil of in vitro propagated Kaempferia galanga Linn. J. Acute Dis. 2014, 3, 124-130. [CrossRef]

36. Kaewkroek, K.; Wattanapiromsakul, C.; Kongsaeree, P.; Tewtrakul, S. Nitric oxide and tumor necrosis factor-alpha inhibitory substances from the rhizomes of Kaempferia marginata. Nat. Prod. Commun. 2013, 8, 1205-1208. [CrossRef] [PubMed]

37. Kaewkroek, K.; Wattanapiromsakul, C.; Matsuda, H.; Nakamura, S.; Tewtrakul, S. Anti-inflammatory activity of compounds from Kaempferia marginata rhizomes. Songklanakarin J. Sci. Technol. 2017, 39, 91-99. 
38. Sematong, T.; Reutrakul, V.; Tuchinda, P.; Claeson, P.; Pongprayoon, U.; Nahar, N. Topical antiinflammatory activity of two pimarane diterpenes from Kaempferia pulchra. Phytother. Res. 1996, 10, 534-535. [CrossRef]

39. Sae-wong, C.; Tansakul, P.; Tewtrakul, S. Anti-inflammatory mechanism of Kaempferia parviflora in murine macrophage cells (RAW 264.7) and in experimental animals. J. Ethnopharmacol. 2009, 124, 576-580. [CrossRef]

40. Lee, M.-h.; Han, A.-R.; Jang, M.; Choi, H.-K.; Lee, S.-Y.; Kim, K.-T.; Lim, T.-G. Antiskin inflammatory activity of black ginger (Kaempferia parviflora) through antioxidative activity. Oxidative Med. Cell. Longev. 2018, 2018, 5967150. [CrossRef]

41. Kobayashi, H.; Suzuki, R.; Sato, K.; Ogami, T.; Tomozawa, H.; Tsubata, M.; Ichinose, K.; Aburada, M.; Ochiai, W.; Sugiyama, K. Effect of Kaempferia parviflora extract on knee osteoarthritis. J. Nat. Med. 2018, 72, 136-144. [CrossRef]

42. Umar, M.I.; Asmawi, M.Z.; Sadikun, A.; Majid, A.M.S.A.; Al-Suede, F.S.R.; Hassan, L.E.A.; Altaf, R.; Ahamed, M.B.K. Ethyl-p-methoxycinnamate isolated from Kaempferia galanga inhibits inflammation by suppressing interleukin-1, tumor necrosis factor- $\alpha$, and angiogenesis by blocking endothelial functions. Clinics 2014, 69, 134-144. [CrossRef]

43. Tewtrakul, S.; Subhadhirasakul, S.; Karalai, C.; Ponglimanont, C.; Cheenpracha, S. Anti-inflammatory effects of compounds from Kaempferia parviflora and Boesenbergia pandurata. Food Chem. 2009, 115, 534-538. [CrossRef]

44. Tewtrakul, S.; Subhadhirasakul, S. Effects of compounds from Kaempferia parviflora on nitric oxide, prostaglandin E2 and tumor necrosis factor-alpha productions in RAW264. 7 macrophage cells. J. Ethnopharmacol. 2008, 120, 81-84. [CrossRef] [PubMed]

45. Jagadish, P.C.; Latha, K.P.; Mudgal, J.; Nampurath, G.K. Extraction, characterization and evaluation of Kaempferia galanga L.(Zingiberaceae) rhizome extracts against acute and chronic inflammation in rats. J. Ethnopharmacol. 2016, 194, 434-439. [CrossRef] [PubMed]

46. Sawasdee, P.; Sabphon, C.; Sitthiwongwanit, D.; Kokpol, U. Anticholinesterase activity of 7-methoxyflavones isolated from Kaempferia parviflora. Phytother. Res. 2009, 23, 1792-1794. [CrossRef]

47. Azuma, T.; Kayano, S.-i.; Matsumura, Y.; Konishi, Y.; Tanaka, Y.; Kikuzaki, H. Antimutagenic and $\alpha$-glucosidase inhibitory effects of constituents from Kaempferia parviflora. Food Chem. 2011, 125, 471-475. [CrossRef]

48. Ochiai, W.; Kobayashi, H.; Kitaoka, S.; Kashiwada, M.; Koyama, Y.; Nakaishi, S.; Nagai, T.; Aburada, M.; Sugiyama, K. Effect of the active ingredient of Kaempferia parviflora, 5, 7-dimethoxyflavone, on the pharmacokinetics of midazolam. J. Nat. Med. 2018, 72, 607-614. [CrossRef]

49. Yorsin, S.; Kanokwiroon, K.; Radenahmad, N.; Jansakul, C. Effects of Kaempferia parviflora rhizomes dichloromethane extract on vascular functions in middle-aged male rat. J. Ethnopharmacol. 2014, 156, 162-174. [CrossRef]

50. Othman, R.; Ibrahim, H.; Mohd, M.A.; Mustafa, M.R.; Awang, K. Bioassay-guided isolation of a vasorelaxant active compound from Kaempferia galanga L. Phytomedicine 2006, 13, 61-66. [CrossRef]

51. Wattanapitayakul, S.K.; Chularojmontri, L.; Herunsalee, A.; Charuchongkolwongse, S.; Chansuvanich, N. Vasorelaxation and antispasmodic effects of Kaempferia parviflora ethanolic extract in isolated rat organ studies. Fitoterapia 2008, 79, 214-216. [CrossRef]

52. Pripdeevech, P.; Pitija, K.; Rujjanawate, C.; Pojanagaroon, S.; Kittakoop, P.; Wongpornchai, S. Adaptogenic-active components from Kaempferia parviflora rhizomes. Food Chem. 2012, 132, 1150-1155. [CrossRef]

53. Matsushita, M.; Yoneshiro, T.; Aita, S.; Kamiya, T.; Kusaba, N.; Yamaguchi, K.; Takagaki, K.; Kameya, T.; Sugie, H.; Saito, M. Kaempferia parviflora extract increases whole-body energy expenditure in humans: Roles of brown adipose tissue. J. Nutr. Sci. Vitaminol. 2015, 61, 79-83. [CrossRef] [PubMed]

54. Wattanathorn, J.; Muchimapura, S.; Tong-Un, T.; Saenghong, N.; Thukhum-Mee, W.; Sripanidkulchai, B. Positive modulation effect of 8-week consumption of Kaempferia parviflora on health-related physical fitness and oxidative status in healthy elderly volunteers. Evid. Based Complementary Altern. Med. 2012, 2012, 732816. [CrossRef] [PubMed]

55. Kobayashi, S.; Kato, T.; Azuma, T.; Kikuzaki, H.; Abe, K. Anti-allergenic activity of polymethoxyflavones from Kaempferia parviflora. J. Funct. Foods 2015, 13, 100-107. [CrossRef] 
56. Plaingam, W.; Sangsuthum, S.; Angkhasirisap, W.; Tencomnao, T. Kaempferia parviflora rhizome extract and Myristica fragrans volatile oil increase the levels of monoamine neurotransmitters and impact the proteomic profiles in the rat hippocampus: Mechanistic insights into their neuroprotective effects. J. Tradit. Complementary Med. 2017, 7, 538-552. [CrossRef] [PubMed]

57. Ali, M.S.; Dash, P.R.; Nasrin, M. Study of sedative activity of different extracts of Kaempferia galanga in Swiss albino mice. BMC Complementary Altern. Med. 2015, 15, 158. [CrossRef] [PubMed]

58. Ridtitid, W.; Sae-Wong, C.; Reanmongkol, W.; Wongnawa, M. Antinociceptive activity of the methanolic extract of Kaempferia galanga Linn. in experimental animals. J. Ethnopharmacol. 2008, 118, 225-230. [CrossRef] [PubMed]

59. Shanbhag, T.V.; Sharma, C.; Adiga, S.; Bairy, K.; Shenoy, S.; Shenoy, G. Wound healing activity of alcoholic extract of Kaempferia galanga in Wistar rats. Indian J. Physiol. Pharmacol. 2006, 50, 384-390.

60. Temkitthawon, P.; Hinds, T.R.; Beavo, J.A.; Viyoch, J.; Suwanborirux, K.; Pongamornkul, W.; Sawasdee, P.; Ingkaninan, K. Kaempferia parviflora, a plant used in traditional medicine to enhance sexual performance contains large amounts of low affinity PDE5 inhibitors. J. Ethnopharmacol. 2011, 137, 1437-1441. [CrossRef]

61. Stein, R.A.; Schmid, K.; Bolivar, J.; Swick, A.G.; Joyal, S.V.; Hirsh, S.P. Kaempferia parviflora ethanol extract improves self-assessed sexual health in men: A pilot study. J. Integr. Med. 2018, 16, 249-254. [CrossRef]

62. Horigome, S.; Maeda, M.; Ho, H.-J.; Shirakawa, H.; Komai, M. Effect of Kaempferia parviflora extract and its polymethoxyflavonoid components on testosterone production in mouse testis-derived tumour cells. J. Funct. Foods 2016, 26, 529-538. [CrossRef]

63. Lert-Amornpat, T.; Maketon, C.; Fungfuang, W. Effect of Kaempferia parviflora on sexual performance in streptozotocin-induced diabetic male rats. Andrologia 2017, 49, e12770. [CrossRef]

64. Lee, S.; Kim, C.; Kwon, D.; Kim, M.-B.; Hwang, J.-K. Standardized Kaempferia parviflora Wall. ex Baker (Zingiberaceae) extract inhibits fat accumulation and muscle atrophy in ob/ob mice. Evid. Based Complementary Altern. Med. 2018, 2018, 8161042. [CrossRef]

65. Ono, S.; Yoshida, N.; Maekawa, D.; Kitakaze, T.; Kobayashi, Y.; Kitano, T.; Fujita, T.; Okuwa-Hayashi, H.; Harada, N.; Nakano, Y. 5-Hydroxy-7-methoxyflavone derivatives from Kaempferia parviflora induce skeletal muscle hypertrophy. Food Sci. Nutr. 2019, 7, 312-321. [CrossRef]

66. Jin, S.; Lee, M.-Y. Kaempferia parviflora extract as a potential anti-acne agent with anti-inflammatory, sebostatic and anti-propionibacterium acnes activity. Int. J. Mol. Sci. 2018, 19, 3457. [CrossRef]

67. Kongdang, P.; Jaitham, R.; Thonghoi, S.; Kuensaen, C.; Pradit, W.; Ongchai, S. Ethanolic extract of Kaempferia parviflora interrupts the mechanisms-associated rheumatoid arthritis in SW982 culture model via p38/STAT1 and STAT3 pathways. Phytomedicine 2019, 59, 152755. [CrossRef]

68. Dash, P.R.; Mou, K.M.; Erina, I.N.; Ripa, F.A.; Al Masud, K.N.; Ali, M.S. Study of anthelmintic and insecticidal activities of different extracts of Kaempferia galanga. Int. J. Pharm. Sci. Res. 2017, 8, 729-733.

69. Jaipetch, T.; Reutrakul, V.; Tuntiwachwuttikul, P.; Santisuk, T. Flavonoids in the black rhizomes of Boesenbergia panduta. Phytochemistry 1983, 22, 625-626. [CrossRef]

70. Herunsalee, A.; Pancharoen, O.; Tuntiwachwuttikul, P. Further studies of flavonoids of the black rhizome Boesenbergia pandurata. J. Sci. Soc. Thail. 1987, 13, 119-122.

71. Trakoontivakorn, G.; Nakahara, K.; Shinmoto, H.; Takenaka, M.; Onishi-Kameyama, M.; Ono, H.; Yoshida, M.; Nagata, T.; Tsushida, T. Structural analysis of a novel antimutagenic compound, 4-hydroxypanduratin A, and the antimutagenic activity of flavonoids in a Thai spice, fingerroot (Boesenbergia pandurata Schult.) against mutagenic heterocyclic amines. J. Agric. Food Chem. 2001, 49, 3046-3050. [CrossRef]

72. Raina, A.P.; Abraham, Z. Chemical profiling of essential oil of Kaempferia galanga L. germplasm from India. J. Essent. Oil Res. 2016, 28, 29-34. [CrossRef]

73. Wong, K.; Ong, K.; Lim, C. Compositon of the essential oil of rhizomes of kaempferia galanga L. Flavour Fragr. J. 1992, 7, 263-266. [CrossRef]

74. Win, N.N.; Ito, T.; Aimaiti, S.; Imagawa, H.; Ngwe, H.; Abe, I.; Morita, H. Kaempulchraols A-H, diterpenoids from the rhizomes of Kaempferia pulchra collected in Myanmar. J. Nat. Prod. 2015, 78, 1113-1118. [CrossRef]

75. Thongnest, S.; Mahidol, C.; Sutthivaiyakit, S.; Ruchirawat, S. Oxygenated pimarane diterpenes from Kaempferia marginata. J. Nat. Prod. 2005, 68, 1632-1636. [CrossRef]

76. Prawat, U.; Tuntiwachwuttikul, P.; Taylor, W.C.; Engelhardt, L.M.; Skelton, B.; White, A. Diterpenes from a Kaempferia species. Phytochemistry 1993, 32, 991-997. [CrossRef] 
77. Sutthanut, K.; Sripanidkulchai, B.; Yenjai, C.; Jay, M. Simultaneous identification and quantitation of 11 flavonoid constituents in Kaempferia parviflora by gas chromatography. J. Chromatogr. A 2007, 1143, 227-233. [CrossRef]

78. Umar, M.I.; Asmawi, M.Z.B.; Sadikun, A.; Altaf, R.; Iqbal, M.A. Phytochemistry and medicinal properties of Kaempferia galanga L. (Zingiberaceae) extracts. Afr. J. Pharm. Pharmacol. 2011, 5, 1638-1647. [CrossRef]

79. Azuma, T.; Tanaka, Y.; Kikuzaki, H. Phenolic glycosides from Kaempferia parviflora. Phytochemistry 2008, 69, 2743-2748. [CrossRef]

80. Davis, E.M.; Croteau, R. Cyclization enzymes in the biosynthesis of monoterpenes, sesquiterpenes, and diterpenes. Top. Curr. Chem. 2000, 209, 53-95.

81. Xu, M.; Hillwig, M.L.; Tiernan, M.S.; Peters, R.J. Probing labdane-related diterpenoid biosynthesis in the fungal genus Aspergillus. J. Nat. Prod. 2017, 80, 328-333. [CrossRef]

82. Li, Y.C.; Ji, H.; Li, X.H.; Zhang, H.X.; Li, H.T. Isolation of nematicidal constituents from essential oil of Kaempferia galanga L rhizome and their activity against Heterodera avenae Wollenweber. Trop. J. Pharm. Res. 2017, 16, 59-65. [CrossRef]

83. Munda, S.; Saikia, P.; Lal, M. Chemical composition and biological activity of essential oil of Kaempferia galanga: A review. J. Essent. Oil Res. 2018, 30, 303-308. [CrossRef]

84. Labrooy, C.D.; Abdullah, T.L.; Stanslas, J. Identification of ethnomedicinally important Kaempferia L. (Zingiberaceae) species based on morphological traits and suitable DNA region. Curr. Plant Biol. 2018, 14, 50-55. [CrossRef]

(C) 2019 by the authors. Licensee MDPI, Basel, Switzerland. This article is an open access article distributed under the terms and conditions of the Creative Commons Attribution (CC BY) license (http://creativecommons.org/licenses/by/4.0/). 